\title{
Restitution as a Remedy for Breach of Contract: The Case of the Partially Performing Seller
}

\author{
Henry Mather†
}

\author{
All my treasure, which should purchase thee, \\ Sighs, tears, and oaths, and letters, I have spent. \\ Yet no more can be due to me \\ Than at the bargain made was meant. . . .
}

\section{-John Donne, Lovers’ Infinitenessł}

Restitution has long been recognized as an optional remedy for breach of contract, ${ }^{1}$ and most of the rules governing this remedy have been accepted without much controversy. ${ }^{2}$ If the plaintiff is a buyer of property

$\dagger$ Associate Professor of Law, University of South Carolina. I would like to thank James Hodges and Margaret McClurkin for their diligent and capable assistance in preparing this Article.

$\ddagger 1$ THE NORTON ANTHOLOGY OF ENGLISH LITERATURE 1072-73 (M. Abrams 4th ed. 1979).

1. Plaintiffs usually choose an alternative remedy. See RESTATEMENT (SECOND) OF CONTRACTS $\S$ 373 comment a (1979) [hereinafter cited as RESTATEMENT (SECOND)]. The alternative remedies are damages and specific performance. The purpose of damages is to put the plaintiff in a position economically equivalent to the position he would have held, if the contract had been performed (plaintiff's "expectancy"). See, e.g., Hawkins v. McGee, 84 N.H. 114, 117, 146 A. 641, 643 (1929); J. Calamari \& J. Perillo, THE LaW of Contracts $\S 14-4$ (2d ed. 1977); 5 A. CORBIN, CORBIN ON CONTRACTS $\S 992$ (1964); RESTATEMENT OF CONTRACTS $\$ 329$ comment a (1932) [hereinafter cited as RESTATEMENT]. The purpose of specific performance is to approximate the effects of voluntary performance by compelling the defendant to render as nearly as practicable the very performance she promised. See, e.g., Beckwith v. Clark, 188 F. 171, 178 (8th Cir. 1911); 5 A. CoRBIN, supra, \& 1102; 5A A. CORBIN, supra, $\S 1138$; RESTATEMENT, supra, $\S 358(1)$ comment a.

As a remedy for breach, "restitution" means either the restoration of a specific thing or the payment in money of the value of a contractual performance rendered by plaintiff. RESTATEMENT, supra, $\S$ 326(b). There is considerable confusion as to the purpose of the restitutionary remedy. It is sometimes said that the purpose is to restore both parties to their pre-contract positions. See, e.g., Bollenback v. Continental Casualty Co., 243 Or. 498, 518, 414 P.2d 802, 812 (1966); J. CALAMARI \& J. PERILlo, supra, § 15-1; RESTATEMENT (SECOND), supra, \$ 384 comment a. This purpose is unattainable if defendant's gain from plaintiff's performance is greater than or less than plaintiff's loss, and plaintiffs performance is restored not in specie, but in money. Many authorities state that the chief purpose of the restitutionary remedy is to restore plaintiff to his pre-contract position. See, e.g., Acme Process Equip. Co. v. United States, 347 F.2d 509, 530 (Ct. Cl. 1965), rev'd on other grounds, 385 U.S. 138 (1966); J. CAlAMARI \& J. PERILlo, supra, § 15-4; 5 A. CORBIN, supra, § 1102; RESTATEMENT, supra, $\S 347$ comment b. Other authorities state that the purpose of restitution as a remedy for breach of contract is to prevent defendant's unjust enrichment. See RESTATEMENT (SECOND), supra, § 344 comments a \& d, §345 (c), (d) \& comment c, $\$ 373$ comment a.

2. The plaintiff will be given the option to elect restitution only if the defendant's breach is a "total" breach discharging plaintiff's duty of further performance. See, e.g., Neenan v. Otis Elevator 
or services ${ }^{3}$ and has paid all or part of the contract price when the defendant breaches, the plaintiff is entitled to restitution of the money he has paid. When the plaintiff is a seller who has fully performed his side of the bargain, and the breaching defendant owes only a liquidated debt, the plaintiff is limited to an action for the contract price and cannot obtain restitution. $^{5}$ If the plaintiff is a seller who has partially performed, and the partial performance can be restored in specie, the breaching defendant may be ordered to make specific restitution. ${ }^{6}$

A controversial issue arises, however, when plaintiff is a seller who has partially performed, and the partial performance cannot be returned in specie. This Article argues that the partially performing seller should not be awarded money restitution as a remedy for breach and should be lim-

Co., 180 F. 997, 1000 (C.C.S.D.N.Y. 1910), af’d, 194 F. 414 (2d Cir. 1912); Buffalo Builders Supply Co. v. Reeb, 247 N.Y. 170, 159 N.E. 899 (1928); J. CALAMARI \& J. PERILlo, supra note 1, § 15-3; 5 A. CORBIN, supra note $1, \S 1104$; RESTATEMENT, supra note $1, \S 347$ comment e. But see 1 G. PALMER, THE LAW OF RESTITUTION $§ 4.5$ (1978) (discussing exceptions to requirement of total breach). The requisite breach may also be referred to as "material," "essential," "vital," or "substantial." See 5 A. CORBIN, supra note $1, \S 1104$.

If defendant has rendered partial performance but has nevertheless committed a total breach entitling plaintiff to restitution, plaintiff's restitution is dependent upon his restoring (either in specie or in money value) the partial performance rendered by the defendant. $5 \mathrm{~A}$. CORBIN, supra note $1, \S \S$ 1114-1116.

3. Throughout this Article, I use "buyer" as a generic term for buyers of goods, vendees of land, employers, and any others who pay money in exchange for property or services. I use "seller" as a generic term for sellers of goods, vendors of land, employees, and any others who provide property or services in exchange for money. Except for the uncommon barter exchange, all exchange contracts involve a "buyer" and a "seller."

4. E.g., Nash v. Towne, 72 U.S. (5 Wall.) 689, 701-02 (1866); Bush v. Canfield, 2 Conn. 485, 488 (1818); 5 A. CORBIN, supra note $1, \S 1108 ; 1$ G. PALMER, supra note $2, \S 4.3$, at 382.

Under the Uniform Commercial Code, a buyer of goods recovers the money he has paid for those goods. U.C.C. § 2-711(1) (1977). To the extent that the buyer has accepted the goods and failed to effectively revoke acceptance, however, he is limited to an action for damages under $\$ 2-714$. U.C.C. $\S$ 2-711(1) \& comment 1 (1977).

5. E.g., Oliver v. Campbell, 43 Cal. 2d 298, 306, 273 P.2d 15, 20 (1954); Lynch v. Stebbins, 127 Me. 203, 206, 142 A. 735, 736 (1928); J. CALAMARI \& J. PERILLO, supra note 1, § 15-6; 5 A. CORBIN, supra note $1, \S 1110 ; 1$ G. PALMER, supra note $2, \S 4.3$; RESTATEMENT, supra note 1 , $\S 350$; RESTATEMENT (SECOND), supra note $1, \S 373(2)$.

Similarly, if a seller fully performs a severable portion of a divisible contract and the breaching buyer owes only a liquidated sum of money for that performance, the seller cannot obtain restitution for that performance. E.g., Dibol v. Minott, 9 lowa 403, 405 (1859); J. Calamari \& J. PERILlo, supra note 1 , § 15-6; 5 A. CORBIN, supra note 1 , § 1111; RESTATEMENT, supra note 1 , 3351 .

6. See 1 G. PALMer, supra note $2, \S 4.7$ (a). It is often stated that specific restitution is not available unless money damages and money restitution are inadequate remedies. See, e.g., J. CALAMARI \& J. PERILLO, supra note $1, \S 15-5 ; 5$ A. CORBIN, supra note $1, \S 1120$; RESTATEMENT, supra note $1, \S 354$. But see 1 G. PALMER, supra note $2, \S 4.7$ (a) (observing that such statements are not supported by court decisions); RESTATEMENT (SECOND), supra note 1, § 372 \& Reporter's note (advocating abandonment of requirement that money relief be inadequate).

Issues concerning specific restitution of a seller's partial performance do not arise often. Partial performance usually occurs in cases involving contracts for services, real estate construction, or goods. Services and construction cannot be returned in specie. Under the Uniform Commercial Code, specific restitution for a seller of goods appears to be limited to the relief provided by $\$ 2-702$ (2) (reclamation from insolvent buyer on credit) and $\S 2-507(2)$ (buyer's failure to make effective payment in a cash sale). See R. NORDSTROM, HANDBOOK OF THE LAW OF SALES $\S \S 165,166$ (1970). 
ited to his expectancy damages. Part I surveys the various measures of money restitution used by the courts in this situation. Part II compares the efficiency properties of restitution and expectancy damages and shows that arguments for or against restitution cannot rest on notions of economic efficiency. Part III demonstrates that money restitution for the partially performing seller is incompatible with liberal principles of law. Given its interference with personal liberty, and the lack of a countervailing economic argument, restitution is not a desirable remedy. Part IV concludes that, in fact, the case of a plaintiff seller who has partially performed is an isolated example of an area of restitution law at odds with liberal principles.

\section{The Measure of Money Restitution for Seller's Partial Performance}

Assume that Contractor and Owner enter into a construction contract. Contractor is to build a house on Owner's land for the contract price of $\$ 50,000$. (I will unrealistically assume that the contract price is not due until completion of the house.) Contractor calculates that his total costs will be $\$ 40,000$ and that he will thus make a profit of $\$ 10,000$. As the work progresses, however, Contractor discovers that full performance will actually cost $\$ 60,000$. When Contractor has incurred costs of $\$ 48,000$ in partial performance, Owner repudiates the contract (a total breach). Contractor terminates his work, leaving Owner with a nearly completed house for which Owner has paid nothing. The market value of Contractor's partial performance is $\$ 64,000$ (Owner would have had to spend $\$ 64,000$ to obtain the same work from another contractor). The market value of Contractor's full performance would be $\$ 80,000$ (Owner would have had to spend $\$ 80,000$ to obtain a complete house from another contractor). The nearly completed house has enhanced the value of the Owner's property by $\$ 72,000$. (Assume that for another $\$ 18,000$, Owner can have a finished house adding $\$ 90,000$ to the value of her real estate.)

If Contractor sues Owner for breach of contract, he can recover expectancy damages of $\$ 38,000 .^{7}$ What can Contractor recover if he chooses the alternative remedy of restitution ? $^{\mathbf{8}}$ His partial performance cannot be re-

7. Contractor has incurred costs of $\$ 48,000$ and has received no payment. Expectancy damages of $\$ 38,000$ leave Contractor with the $\$ 10,000$ net loss he would have had if the contract had been performed. See supra note 1 (discussing purpose of expectancy damages). If a contractor has partially performed a construction contract when the owner breaches, the contractor's damages usually are the unpaid contract price minus the cost of completion (the cost the contractor would have incurred in finishing the job). See, e.g., Guerini Stone Co. v. Carlin Constr. Co., 240 U.S. 264 (1916); Millen v. Gulesian, 229 Mass. 27, 118 N.E. 267 (1918); J. CALAMARI \& J. PERILLO, supra note 1, § 14-28; 5 $\Lambda$. CORBIN, supra note $1, \S 1094$; RESTATEMENT, supra note $1, \S 346(2)(\mathrm{a})$. In our hypothetical, the unpaid contract price is $\$ 50,000$ and the cost of completion is $\$ 12,000$. (Contractor has already spent $\$ 48,000$, and total costs would be $\$ 60,000$.) Contractor's expectancy damages are thus $\$ 38,000$.

8. Although market value of the partial performance is the prevailing measure, a number of 
turned in specie, so restitution will be in the form of money. How much money?

\section{A. Market Value of Seller's Partial Performance}

The prevailing view is that a seller's restitutionary recovery is measured by the market value of his partial performance (as of the time of performance), even if this market value exceeds the contract rate for such partial performance or exceeds the contract price for full performance. ${ }^{\theta}$ Under this rule, Contractor would recover $\$ 64,000$ as restitution for Owner's breach.

Market value restitution enables Contractor to avoid the loss he would have suffered had the contract been performed. Full performance would have yielded Contractor a net loss of $\$ 10,000$ ( $\$ 50,000$ contract price minus $\$ 60,000$ costs). As a result of Owner's breach and a market value restitutionary recovery, Contractor obtains from his partial performance a $\$ 16,000$ net profit ( $\$ 64,000$ restitution minus $\$ 48,000$ costs). Contractor also receives more gross income for partial performance than he would have received for full performance. If Contractor had fully performed, restitution would be precluded by the full performance rule, ${ }^{10}$ and Contractor would be limited to an action for the $\$ 50,000$ contract price. But because he has only partially performed, he obtains $\$ 64,000$ by way of restitution. Market value restitution thus provides greater reward for less work.

Perhaps the best explanation for the prevailing rule is that market value is a good proxy for the value to both parties of plaintiff's partial performance. When Contractor provides a partial performance having a market value of $\$ 64,000$, he gives up labor and resources he could have sold in the marketplace for $\$ 64,000$; he has thus suffered an opportunity cost of $\$ 64,000$. Owner has gained something for which she would have had to pay $\$ 64,000$ in the marketplace. A restitutionary transfer of $\$ 64,000$ from Owner to Contractor would thus seem to deprive Owner of

courts have rejected it, thus provoking debate among the commentators. Compare Childres \& Garamella, The Law of Restitution and the Reliance Interest in Contract, 64 NW. U.L. REV. 433 (1969) (generally favoring contract rate restitution) with Palmer, The Contract Price as a Limit on Restitution for Defendant's Breach, 20 OHIO ST. L.J. 264, 268-79 (1959) (favoring market value restitution without contract price or contract rate limitation). Many of the conflicting arguments are summarized in D. DOBBS, HANDBOOK ON THE LAW OF REMEDIES $\$ 4.5$, at 271-73, § 12.1, at 794-95, $\S 12.24$, at $915-18$ (1973).

9. See, e.g., United States ex rel. Building Rentals Corp. v. Western Casualty \& Sur. Co., 498 F.2d 335 (9th Cir. 1974); United States ex rel. Coastal Steel Erectors, Inc. v. Algernon Blair, Inc., 479 F.2d 638 (4th Cir. 1973); United States ex rel. Citizens Nat'l Bank v. Stringfellow, 414 F.2d 696 (5th Cir. 1969); Scaduto v. Orlando, 381 F.2d 587 (2d Cir. 1967); Posner v. Seder, 184 Mass. 331, 68 N.E. 335 (1903); 5 A. CORBIN, supra note $1, \S \S 1112,1113 ; 1$ G. PALMER, supra note $2, \S \S 4.2$, 4.4(a)-(b); RESTATEMENT, supra note $1, \S 347$ \& comment $c$.

10. See supra p. 15. 
her unjust gain and restore to Contractor the very value he had lost.

This explanation is untenable, however, in view of the rule that a plaintiff-seller recovers the market value of any bargained-for performance, even if defendant never derived any economic benefit from it. ${ }^{11}$ As Corbin observes:

It is clear that the availability of restitution as a remedy for breach of contract does not depend wholly upon the idea that the defendant has been unjustly enriched by the part performance rendered by the plaintiff. There need be no addition to his material wealth, either permanent or temporary. ${ }^{12}$

Restitution, then, need not restore each party to the status quo ante; instead, courts often seem to compensate the plaintiff for a lost market opportunity, regardless of the effect on the breaching party.

\section{B. Market Value with Contract Price Ceiling}

A few decisions allow the plaintiff seller to recover market value restitution for partial performance, but do not permit such recovery to exceed the total contract price. ${ }^{13}$ This prevents the seller from receiving more gross revenue for partial performance than he could have received for full performance. In our hypothetical, Contractor would obtain restitution of $\$ 50,000$ under this rule; although the market value of his part performance was $\$ 64,000$, the contract price was only $\$ 50,000$.

A contract price ceiling on market value restitution reflects the unwillingness of some courts to ignore completely the terms of contracts; the plaintiff ought not recover more than he could have earned under the contract terms.

\section{Contract Rate as the Measure of Restitution}

Some courts have used the contract rate as the measure of restitution for seller's part performance; plaintiff seller receives only the amount that, according to the contract terms, has been earned by his part performance. If the contract price was expressed in dollars per unit of performance, the seller recovers at that contract rate for the units he has performed. ${ }^{14}$

If the contract price was not expressed in dollars per unit of perform-

11. For discussion of the rule, see 5 A. CORBIN, supra note $1, \S 1107 ; 1$ G. PALMER, supra note 2 , $\$ 4.2$; RESTATEMENT, supra note $1, \S 348$ comment a.

12. 5 A. CORBIN, supra note $1, \S 1107$, at 577 .

13. See Johnson v. Bovee, 40 Colo. App. 317, 574 P.2d 513 (1978); Harrison v. Hancock, 2 Neb. 522, 89 N.W. 374 (1902); Wuchter v. Fitzgerald, 83 Or. 672, 163 P. 819 (1917).

14. Kehoe v. Mayor of Rutherford, 56 N.J.L. 23, 27 A. 912 (1893); Doolittle v. McCullough, 12 Ohio St. 360 (1861); Bailey v. Furleigh, 121 Wash. 207, 208 P. 1091 (1922). 
ance, but only as a lump sum, contract rate restitution is computed by prorating the contract price. Courts have performed the allocation in two ways. Under the first method, seller's restitutionary recovery bears the same ratio to the total contract price as the market value of seller's part performance bears to the market value of seller's full performance. ${ }^{15}$ Under the second method, seller's restitutionary recovery bears the same ratio to the total contract price as seller's cost incurred in part performance bears to the total cost seller would have incurred in full performance. ${ }^{16}$ In our hypothetical, Contractor would recover $\$ 40,000$ under either method.17

Contractor's $\$ 40,000$ recovery at the contract rate is less than the $\$ 64,000$ he would receive if restitution were measured by the market value of his part performance. It is also less than the $\$ 50,000$ he would recover if the court used market value with a contract price ceiling. But it is more than the $\$ 38,000$ he would recover as expectancy damages.

Contract rate restitution gives the plaintiff seller that portion of his total expectancy allocable to his part performance, but it ignores that portion of his total expectancy allocable to the remainder of the contract. In our hypothetical, Gontractor's total expectancy is a $\$ 10,000$ net loss. He has performed four-fifths of his contract (measured on either a cost or market value basis). Contract rate restitution of $\$ 40,000$ leaves him with a net loss of $\$ 8000$ (he has incurred costs of $\$ 48,000$ and received $\$ 40,000$ restitution); this is four-fifths of his total expectancy.

\section{Restitution Measured by Seller's Costs Incurred}

At least one decision indicates that the proper measure of restitution for a seller's partial performance is the seller's costs incurred in good faith. ${ }^{18}$ In our hypothetical, restitution measured by Contractor's costs would amount to $\$ 48,000$. Although this is less than market value restitution $(\$ 64,000)$ and less than market value restitution with a contract price ceil-

15. This appears to be the method adopted in Noyes v. Pugin, 2 Wash. 653, 27 P. 548 (1891).

16. This is the method the trial court used in Kehoe v. Mayor of Rutherford, 56 N.J.L. 23, 27 A. 912 (1893).

17. The relevant ratio for the percentage-of-market value method is $40,000 / 50,000=64,000$ / 80,000 . The corresponding ratio for the percentage-of-cost method is $40,000 / 50,000=48,000$ / 60,000 . The percentage-of-market value method and the percentage-of-cost method will not always produce the same result. For example, a contractor may have incurred one-half of his total costs and yet have provided labor and materials having a market value that is only two-fifths of the market value of full performance.

18. See Philadelphia v. Tripple, $230 \mathrm{~Pa}$. 480, 79 A. 703 (1911) (suggesting that seller can recover his costs even though they exceed the contract price). Some decisions recognize market value as the normal measure of restitution but permit restitution to be measured by seller's reasonable costs if there is no contrary evidence of market value. United States ex rel. Susi Contracting Co. v. Zara Contracting Co., 146 F.2d 606 (2d Cir. 1944); Acme Process Equip. Co. v. United States, 347 F.2d 509 (C.. Cl. 1965), rev'd on other grounds, 385 U.S. 138 (1966). 
ing $(\$ 50,000)$, it exceeds contract rate restitution $(\$ 40,000)$ and Contractor's expectancy damages $(\$ 38,000)$.

If restitution measured by seller's costs incurred is designed to restore seller to his pre-contract position, it would frequently fail to achieve its purpose. Cost restitution compensates the partially performing seller only for explicit costs and does not compensate for any profit he could have made by selling his output to someone other than the defendant buyer, an opportunity seller had in the pre-contract position, but gave up in contracting with the defendant.

\section{E. Measuring Restitution by Defendant's Economic Gain}

If eliminating defendant buyer's unjust enrichment were the goal of the restitutionary remedy, one might expect restitution for seller's partial performance to be measured by defendant's economic gain. In our hypothetical, this would seem to require restitution to Contractor of $\$ 72,000$, the amount by which the value of Owner's property has been increased by Contractor's partial performance. But the courts do not consider the increase in defendant's wealth. The prevailing practice is reflected in the comments to the Restatement of Contracts:

If the plaintiff's performance is part of the very performance for which the defendant bargained as part of an agreed exchange, it is to be valued, not by the extent to which the defendant's total wealth has been increased thereby, but by the amount for which such services and materials as constituted the part performance could have been purchased from one in the plaintiff's position at the time they were rendered. ${ }^{10}$

\section{F. Summary}

We have considered five alternative methods of measuring money restitution as a breach of contract remedy for a seller who has partially performed. ${ }^{20} \mathrm{I}$ have not discussed the relative merit of these alternatives in

19. RESTATEMENT, supra note $1, \S 347$ comment c; see 5 A. CORBIN, supra note $1, \S 1107 ; 1 \mathrm{G}$. PALMER, supra note $2, \S 4.2$.

20. It is not clear whether, under the Uniform Commercial Code, the partially performing seller gets contract rate restitution, market value restitution, or his expectancy. The Code appears to favor contract rate restitution. According to $\S 2-607(1)$, the buyer must pay at the contract rate for any goods accepted. Comment 1 to $\S 2-607$ states that if part of the goods has been delivered and accepted, the price to be paid for the accepted goods is to be reasonably apportioned at the contract rate, using the type of apportionment employed in quantum valebat cases. In those cases, however, the courts award "reasonable value" (market value). See Bartow Guano Co. v. Adair, 29 Ga. App. 644, 116 S.E. 342 (1923); D. DOBBS, supra note $8, \S 4.2$, at 237-38.

Indeed, some commentators have argued that market value restitution is available in cases governed by the Code, since seller can cancel the contract under $\S 2-703(f)$ and, thus, under $\S 1-103$ (which supplements Code provisions with general principles of law and equity) become entitled to the com- 
detail because I shall argue that, regardless of the measure used, money restitution is an improper remedy for breach of contract when the plaintiff is a partially performing seller. Such a plaintiff should be limited to his expectancy damages.

\section{Restitution and Expectancy Damages: An Economic Analysis}

As noted above, the prevailing view allows a partially performing seller to elect market value restitution as a remedy for the buyer's breach of contract (assuming that specific restitution is not appropriate). It has been argued, however, that restitution is less efficient than expectancy damages. In fact, this is so only if one ignores transaction costs. When transaction costs are taken into account, expectancy damages may not be more efficient than restitution.

\section{A. Expectancy Damages and the Theory of Efficient Breach}

The economic argument for expectancy damages asserts that in some situations, breach is more efficient than performance of the contract, and the expectancy damages remedy encourages breach, whereas market value restitution ${ }^{21}$ encourages performance. When, in the absence of any legal remedy, $D$ 's incremental gain from her own breach exceeds $P$ 's incremental loss, breach is more efficient in terms of aggregate welfare than performance. ${ }^{22}$ If, in such situations, the only legal remedy for breach is expectancy damages, then $D$ will breach and pay expectancy damages that compensate $P$ for his loss. This will leave $P$ in the same economic position he would have been in had $D$ performed, and $D$ will still be better off than she would have been had she performed. ${ }^{23}$ Since one party is made better off and the other party no worse off, aggregate welfare has been

mon law remedy available to a seller who has rescinded upon buyer's breach: market value restitution. See Nordstrom, Restitution on Default and Article Two of the Uniform Commercial Code, 19 VAND. L. REV. 1143, 1166 (1966); see also 1 G. PALMER, supra note 2, § 4.16(a) (stating that Code remedies should not be regarded as exclusive). This argument is a weak one, however, because $\$ 2-703$ permits a seller to cancel only with respect to the undelivered balance.

It can also be argued that seller cannot recover more for his part performance than the amount that gives him his expectancy. According to $\S 1-106(1)$, remedies should put plaintiff in as good a position as if the other party had fully performed. If "as good a position" means no worse and no better, no remedy for breach should give plaintiff more than his expectancy.

21. Expectancy damages will be compared only with market value restitution, but the same conclusion would follow from a comparison to any of the alternative measures of money restitution, each of which can result in a restitutionary recovery exceeding expectancy damages. Thus, each could induce contractual performance where expectancy damages would induce breach.

22. See R. POSNER, ECONOMIC ANALYSIS OF LAW $\S 4.9$ (2d ed. 1977); Birmingham, Breach of Contract, Damage Measures, and Economic Efficiency, 24 RUTGERS L. REV. 273, 284 (1970).

23. "Repudiation of obligations should be encouraged where the promisor is able to profit from his default after placing his promisee in as good a position as he would have occupied had performance been rendered." Birmingham, supra note 22, at 284. 
increased. ${ }^{24}$ If, on the other hand, market value restitution is an available remedy, $D$ may be deterred from breaching. Market value restitution will be selected by $P$ only if it provides a greater recovery than expectancy damages. If $D$ 's potential restitutionary liability is great enough, she will be deterred from breach, even though breach is more efficient than performance.

The economic argument for expectancy damages can be illustrated by adding one fact to our original Contractor/Owner example. Assume the following:

$\begin{array}{lr}\text { Contract Price } & \$ 50,000 \\ \text { Contractor's estimated costs } & 40,000 \\ \text { Contractor's true costs } & 60,000 \\ \text { Contractor's cost incurred in part } & \\ \quad \text { performance } & 48,000 \\ \text { Market value of part performance } & 64,000 \\ \text { Owner's cost to complete upon breach } & \\ \quad \text { (the new fact) } & 10,000\end{array}$

If Contractor's sole remedy is to recover expectancy damages, Owner will breach. If Owner breaches, she must pay expectancy damages of $\$ 38,000$ (the amount that leaves Contractor with the $\$ 10,000$ net loss he would have incurred upon full performance) and must also pay another contractor $\$ 10,000$ to get the house completed; thus if Owner breaches, she can have her house for $\$ 48,000$. But if Owner performs, she must pay $\$ 50,000$ (the contract price) for the house.

If market value restitution is an available remedy for Contractor, Owner will perform rather than breach. If Owner breaches, she must pay Contractor $\$ 64,000$ as restitution and must also pay another contractor $\$ 10,000$ to complete the house, a total of $\$ 74,000$. If Owner performs, she need only pay the $\$ 50,000$ contract price.

In this situation, it is more efficient for Owner to breach and pay expectancy damages than to perform. In either event, Contractor ends up with a $\$ 10,000$ net loss. But Owner saves $\$ 2000$ by breaching and paying expectancy damages. The expectancy damages remedy is preferable to market value restitution because it induces the more efficient use of resources.

24. The expectancy damages remedy is consistent with a cautious policy of encouraging breach only when it is certain that breach increases aggregate utility. If, in terms of dollar gains and losses, breach followed by payment of expectancy damages is advantageous to one party and neither advantageous nor disadvantageous to the other party, then breach increases aggregate utility, regardless of either party's marginal utility of income curve. The theory of efficient breach assumes that expectancy damages encourage breach only in such situations. 


\section{B. Relative Efficiency of Expectancy Damages and Market Value Resti- tution When Transaction Costs Are Considered}

The theory of efficient breach ignores certain transaction costs incurred as a result of a breach of contract. Inasmuch as a winning plaintiff does not recover attorneys' fees or other litigation expenses and usually does not receive fully compensatory interest for the delay in recovering damages, the expectancy remedy does not fully compensate a plaintiff for losses caused by the defendant's breach. ${ }^{25}$ The theory of efficient breach proceeds on the assumption that expectancy damages put plaintiff in the same economic position as would performance. We must therefore reevaluate the relative economic efficiency of market value restitution and expectancy damages, this time considering the effects of breach-related transaction costs.

Which of these two remedies is more likely to induce $D$ (the party contemplating breach) to breach when, and only when, breach is efficient? In assessing the relative economic efficiency of breach and performance, we shall employ two welfare criteria: Pareto superiority and Kaldor-Hicks superiority.

An allocation A1 of economic resources is Pareto-superior to an alternative allocation A2 if and only if $\mathrm{A} 1$ makes at least one person better off than $\mathrm{A} 2$ does and makes no one worse off than A2 does. ${ }^{28}$ Thus, a transaction involving a $\$ 2000$ net gain for $D$ and a $\$ 500$ net gain for $P$ is Pareto-superior to a transaction involving a $\$ 1000$ net gain for $D$ and a $\$ 500$ net gain for $P$.

An allocation A1 of economic resources is Kaldor-Hicks-superior to an alternative allocation A2 if and only if the persons made better off by A1 could fully compensate any persons made worse off and still have net gains in economic welfare. ${ }^{27}$ Thus, a transaction involving a $\$ 2000$ net gain for $D$ and a $\$ 500$ net gain for $P$ is Kaldor-Hicks-superior (though not Pareto-superior) to a transaction involving a $\$ 1000$ net gain for $D$ and a $\$ 1000$ net gain for $P .^{28}$

25. This has been noted by a number of commentators. See Birmingham, supra note 22, at 285; Carroll, Four Games and the Expectancy Theory, 54 S. CAL. L. REV. 503, 512, 514 (1981); Farber, Reassessing the Economic Efficiency of Compensatory Damages for Breach of Contract, 66 VA. L. REV. 1443, 1444, 1450-51 (1980); Macneil, Efficient Breach of Contract: Circles in the Sky, 68 VA. L. REV. 947 (1982); Vernon, Expectancy Damages for Breach of Contract: A Primer and Critique, 1976 WASH. U.L.Q. 179, 186, 202.

26. Coleman, Efficiency, Utility, and Wealth Maximization, 8 HOFSTRA L. REV. 509, 513 (1980); see J. HENDERSON \& R. QUANDT, MICROECONOMIC THEORY 286 (3d ed. 1980); C. ROWLEY \& A. PEACOCK, WELFARE ECONOMICS 9 (1975); Coleman, Efficiency, Exchange and Auction: Philosophic Aspects of the Economic Approach to Law, 68 CALIF. L. REV. 221, 226 (1980).

27. Coleman, Efficiency, Utility, and Wealth Maximization, supra note 26, at 513; see also M. DOBB, WELFARE ECONOMICS AND THE ECONOMICS OF SOCIALISM 82-83 (1975) (describing development of Kaldor-Hicks test).

28. I follow Richard Posner in applying the Kaldor-Hicks test by comparing gains and losses in 


\section{Pareto Superiority}

Are there any situations in which a legal rule allowing market value restitution produces outcomes Pareto-superior to those that would result if expectancy damages were the only available remedy for breach?

Let us first ask whether there could be a situation in which market value restitution would induce $D$ to perform, expectancy damages would induce $D$ to breach, and performance is Pareto-superior to breach with expectancy damages. Such a situation is impossible. If the use of expectancy damages would induce $D$ to breach, $D$ must be better off breaching and paying expectancy damages (incurring whatever breach-related transaction costs are necessary) than she would be if she performs. ${ }^{29}$ Since performance would make $D$ worse off, it cannot be Pareto-superior to breach with expectancy damages.

Let us now ask whether there could be a situation in which market value restitution would induce $D$ to breach, expectancy damages would induce $D$ to perform, and breach with market value restitution is Paretosuperior to performance. The answer is again negative. There is no situation in which market value restitution would induce $D$ to breach and expectancy damages would induce $D$ to perform. This would require that expectancy damages exceed market value restitution, ${ }^{30}$ in which case $P$ would not elect restitution.

We thus arrive at Conclusion One: A legal rule allowing market value restitution will never induce outcomes Pareto-superior to those induced by a rule allowing only expectancy damages.

wealth, measured in dollar values. See Posner, The Ethical and Political Basis of the Efficiency Norm in Common Law Adjudication, 8 HOFSTRA L. REV. 487, 490-91 (1980). So applied, the KaldorHicks test is essentially equivalent to Posner's wealth maximization test. Coleman, Efficiency, Exchange, and Auction, supra note 26, at 239-42; Posner, supra, at 491. In this form, the Kaldor-Hicks test avoids the Scitovsky paradox, which arises when a move from allocation A1 to allocation A2 is Kaldor-Hicks efficient, and a move back from A2 to A1 is also Kaldor-Hicks efficient. When gains and losses are measured in dollars, one party's dollar gain in moving from one allocation to the other is equal to his dollar loss in moving in the opposite direction. Thus, if a move from allocation A2 to allocation $A 1$ gives $D$ a dollar gain exceeding $P$ 's dollar loss, a move in the opposite direction cannot possibly give $P$ a dollar gain exceeding $D$ 's dollar loss.

This formulation of the Kaldor-Hicks test, however, suffers from a more serious problem. Because the test measures gains and losses in dollars, Kaldor-Hicks superiority does not guarantee an increase in aggregate utility. In the example used in the text, $\$ 500$ may bring more utility to $P$ than $\$ 1000$ brings to $D$. If so, the transaction involving a $\$ 2000$ net gain for $D$ does not produce greater aggregate utility, even though it is Kaldor-Hicks-superior to the other transaction. For discussions of the Scitovsky paradox and the discrepancy between Kaldor-Hicks superiority and utility maximization, see W. BAUMOL, ECONOMIC THEORY AND OPERATIONS ANALYSIS 528-30 (4th ed. 1977); Coleman, Efficiency, Utility, and Wealth Maximization, supsa note 26, at 518-20.

29. In performing economic analysis, I assume that each party is rational, fully informed as to the facts and the law, and motivated solely by self-interest.

30. I assume that $D^{\prime}$ s breach-related transaction costs are the same, whichever remedy is granted to $P$. If expectancy damages are the only available remedy, it is unlikely that $D$ 's litigation expense will be greater than if $\boldsymbol{P}$ has both remedies available. 
Are there any situations in which a legal rule requiring expectancy damages produces outcomes Pareto-superior to those that result from a rule permitting market value restitution?

We shall first ask whether there could be a situation in which expectancy damages would induce $D$ to perform, market value restitution would induce $D$ to breach, and performance is Pareto-superior to breach with market value restitution. The answer is negative. As we have already seen, there is no situation in which expectancy damages would induce $D$ to perform and market value restitution would induce $D$ to breach. (Furthermore, for restitution to induce $D$ to breach, performance must be worse for $D$ and thus not Pareto-superior.)

Let us now ask whether there could be a situation in which expectancy damages would induce $D$ to breach, market value restitution would induce $D$ to perform, and breach with expectancy damages is Pareto-superior to performance. Again, the answer is negative. Due to litigation expenses and other breach-related transaction costs that are not legally compensable, breach with expectancy damages always makes $\boldsymbol{P}$ worse off than performance. $^{31}$ Such a breach is therefore not Pareto-superior to performance.

We thus arrive at Conclusion Two: A legal rule allowing only expectancy damages will never induce outcomes Pareto-superior to those induced by a rule allowing market value restitution.

Combining Conclusions One and Two, we get Conclusion Three: Neither a rule allowing market value restitution as an optional remedy nor a rule requiring expectancy damages as the only remedy induces outcomes Pareto-superior to those induced by the other rule.

\section{Kaldor-Hicks Superiority}

We must now compare market value restitution and expectancy damages in terms of Kaldor-Hicks superiority. We have already seen that in no situation would market value restitution induce $D$ to breach while expectancy damages would induce $D$ to perform. We may therefore confine our analysis to situations in which market value restitution would induce $D$ to perform and expectancy damages would induce $D$ to breach.

Are there situations in which market value restitution would induce $D$ to perform, expectancy damages would induce $D$ to breach, and performance is Kaldor-Hicks-superior to breach with expectancy damages? Yes,

31. This assumes that $D$ 's breach causes loss to $P$. Expectancy damages do not fully compensate $P$ for that loss. When $D$ 's breach makes $P$ better off than performance would, however, it does not matter what legal remedies are available. If expectancy damages are the exclusive remedy, $D$ will breach. If market value restitution is available, $P$ will induce $D$ to breach by promising not to sue for restitution. 
there are. Consider the following hypothetical in which $P$, a contractor, is engaged to build a garage for $D$ :

$\begin{array}{lr}\text { Contract price for garage (unpaid) } & \$ 10,000 \\ P \text { 's actual costs of full performance } & 15,000 \\ P \text { 's costs incurred in part performance } & 8,000 \\ \text { Market value of } P \text { 's part performance } & 6,000 \\ P \text { 's noncompensable transaction costs resulting } & \\ \quad \text { from } D \text { 's breach } & 3,000 \\ D \text { 's costs of obtaining completion from } & \\ \quad \text { another contractor } & 3,000 \\ D \text { 's transaction costs resulting from breach } & 1,500\end{array}$

$P$ 's expectancy damages would be $\$ 3000$ if $D$ breaches when $P$ has incurred costs of $\$ 8000$ in partial performance (ignoring $P$ 's noncompensable transaction costs, $\$ 3000$ is the amount necessary to leave $P$ with the $\$ 5000$ net loss he would have upon full performance of the contract). If $D$ breaches and pays expectancy damages, $P$ will suffer an $\$ 8000$ net loss ( $\$ 3000$ expectancy damages received from $D$, minus $\$ 8000$ costs of part performance, minus $\$ 3000$ noncompensable transaction costs), and $D$ will have obtained a garage at a total cost of $\$ 7500$ ( $\$ 3000$ expectancy damages paid to $P$, plus $\$ 3000$ paid to another contractor, plus $\$ 1500$ transaction costs). If $D$ performs her contract with $P, P$ will suffer a $\$ 5000$ net loss (the difference between $\$ 15,000$ costs and the $\$ 10,000$ contract price), while $D$ will have obtained a garage for $\$ 10,000$ (the contract price). Performance is Kaldor-Hicks-superior to breach with expectancy damages. Performance makes $P \$ 3000$ better off than breach does and makes $D$ only $\$ 2500$ worse off. Thus $P$ 's incremental gain from performance would make it possible for $P$ to compensate $D$ for $D$ 's incremental loss of $\$ 2500$ and still retain a $\$ 500$ net gain.

$D$ will breach if $P$ 's only available remedy is expectancy damages; breach will give $D$ a garage for $\$ 7500$, whereas peformance would give $D$ a garage for $\$ 10,000$. But if $P$ is allowed to choose market value restitution as an optional remedy, $D$ will perform because breach with restitution would give $D$ a garage at a cost of $\$ 10,500$ ( $\$ 6000$ market value restitution paid to $P$, plus $\$ 3000$ paid to another contractor to complete the garage, plus $\$ 1500$ transaction costs resulting from breach).

Thus, in this situation, market value restitution would induce $D$ to perform, expectancy damages would induce $D$ to breach, and performance is Kaldor-Hicks-superior to breach with expectancy damages. We thus arrive at Conclusion Four: A legal rule allowing market value restitution sometimes induces outcomes Kaldor-Hicks-superior to those induced by a rule allowing only expectancy damages. 
We must now ask whether there are cases in which market value restitution would induce $D$ to perform, expectancy damages would induce $D$ to breach, and breach with expectancy damages is Kaldor-Hicks-superior to performance. There are. Consider the following variation of the previous hypothetical:

Contract price for garage (unpaid)

$P$ 's actual costs of full performance

$P$ 's costs incurred in part performance

Market value of $P$ 's part performance

$P$ 's noncompensable transaction costs resulting from $D$ 's breach

$D$ 's cost of obtaining completion from another contractor

$D$ 's transaction costs resulting from breach
$\$ 10,000$

15,000

8,000

8,000

500

1,500

1,000

As in the previous hypothetical, $P$ 's expectancy is a $\$ 5000$ net loss, and if $D$ breaches when $P$ has incurred costs of $\$ 8000$ in partial performance, $P$ 's expectancy damages would be $\$ 3000$. Thus, if $D$ breaches and pays expectancy damages, she ends up with a garage costing $\$ 5500$ (\$3000 expectancy damages paid to $P$, plus $\$ 1500$ paid to another contractor to complete the garage, plus $\$ 1000$ transaction costs). $P$ ends up with a $\$ 5500$ net loss ( $\$ 3000$ expectancy damages received, minus $\$ 8000$ cost of part performance, minus $\$ 500$ noncompensable transaction costs). If $D$ performs her contract with $P, P$ will end up with a $\$ 5000$ net loss, and $D$ will have a garage costing $\$ 10,000$. In this situation, breach with expectancy damages is Kaldor-Hicks-superior to performance. Breach makes $D$ $\$ 4500$ better off than performance and makes $P$ only $\$ 500$ worse off. D's incremental gain from breach is greater than the amount required to compensate $P$ for his incremental loss.

We can also see that $D$ will breach if expectancy damages are $P$ 's only remedy, since breach gives $D$ a garage for $\$ 5500$, whereas performance would give her a garage for $\$ 10,000$. If $P$ is allowed to choose market value restitution as a remedy, however, $D$ will perform; the market value of $P$ 's part performance is $\$ 8000$, and breach with restitution would result in $D$ 's acquiring a garage costing $\$ 10,500$ ( $\$ 8000$ market value restitution paid to $P$, plus $\$ 1500$ paid to another contractor to complete the garage, plus $\$ 1000$ transaction costs resulting from breach).

In this situation, then, market value restitution would induce $D$ to perform, expectancy damages would induce $D$ to breach, and breach with expectancy damages is Kaldor-Hicks-superior to performance. ${ }^{32}$ We thus

32. If negotiation costs are low enough, $P$ and $D$ can negotiate a mutually advantageous cancella- 
arrive at Conclusion Five: A legal rule allowing only expectancy damages sometimes induces outcomes Kaldor-Hicks-superior to those induced by a rule allowing market value restitution.

Combining Conclusions Four and Five, we get Conclusion Six: Under the criterion of Kaldor-Hicks efficiency, a rule allowing market value restitution is preferable in some situations, while a rule allowing only expectancy damages is preferable in others.

\section{G. The Inconclusiveness of Economic Analysis}

We have inquired whether expectancy damages are really preferable to market value restitution when transaction costs are considered. In view of Conclusions Three and Six, it appears that economic analysis fails to show that either is preferable, whether we use the Pareto or the KaldorHicks standard of efficiency. ${ }^{33}$ The issue, therefore, must be resolved by means of noneconomic principles of justice.

tion of the contract, and the availability of market value restitution will not induce $D$ to perform. $C$. Clarkson, Miller \& Muris, Liquidated Damages v. Penalties: Sense or Nonsense?, 1978 WIS. L. REV. 351, 360-62; Goetz \& Scott, Liquidated Damages, Penalties and the Just Compensation Principle: Some Notes on an Enforcement Model and a Theory of Efficient Breach, 77 CoLUM. L. REV. 554, $567-68,587$ (1977) (suggesting that if nonperformance is efficient, parties can negotiate out of a stipulated damages clause that would deter breach). See generally Coase, The Problem of Social Cost, 3 J.L. \& ECON. 1, 1-16 (1960) (arguing that in the absence of transaction costs, persons with conflicting economic interests can bargain to efficient outcomes, regardless of their legal rights and liabilities). Assuming that negotiation costs are negligible, $D$ would be willing to pay $P$ any amount up to $\$ 8500$ to cancel the contract ( $\$ 8500$ plus the $\$ 1500$ cost of obtaining completion from another contractor equals the $\$ 10,000$ contract price $D$ would pay if the contract were performed). $P$ would accept any amount exceeding $\$ 3000$ ( $\$ 3000$ gives $P$ the $\$ 5000$ net loss he would derive from contract performance).

Similarly, in the previous hypothetical, the availability of market value restitution will not induce $D$ to perform, so long as negotiation costs are low enough to permit $D$ and $P$ to negotiate a mutually advantageous cancellation. Assuming that negotiation costs are negligible, $D$ would be willing to pay $P$ any amount up to $\$ 7000$ to cancel the contract $\$ \$ 7000$ plus the $\$ 3000$ cost of obtaining completion from another contractor equals the $\$ 10,000$ contract price $D$ would pay if the contract were performed). $P$ would accept any amount exceeding $\$ 3000$ ( $\$ 3000$ gives $P$ the $\$ 5000$ net loss he would derive from contract performance).

It is thus possible that in these two hypothetical situations the availability of market value restitution would not result in the performance of contracts that would otherwise go unperformed. In such cases, the availability of market value restitution would not affect economic efficiency.

33. Robert Birmingham recognizes that expectancy damages are undercompensatory and thus fail to achieve the efficient results indicated by the theory of efficient breach. He argues, however, that instead of abandoning the expectancy measure, the legal system should make the breaching party bear the other party's transaction costs caused by the breach. Birmingham, supra note 22, at 285 . Nevertheless, the general rule that each party must bear his own litigation expense will probably persist (although exceptions have been carved out by consumer protection statutes) and should be taken as a "given" when trying to decide whether a partially performing seller should be allowed to select market value restitution as an optional remedy. 


\section{The Liberal Argument Against Money Restitution As a Remedy for Partially Performing Sellers}

Basic liberal principles of justice imply that money restitution is an improper remedy for breach when the plaintiff is a seller who has partially performed. $^{34}$ In this case, restitution interferes unnecessarily with the liberty of the parties.

\section{A. Protection of Liberty as a Goal of the Legal System: The Principle of Minimal Coercion}

According to the liberal view, a legal system should prevent, or at least minimize, harmful invasions of the liberty ${ }^{35}$ of any citizen. ${ }^{36}$ In particular, the legal system should protect each citizen's liberty to dispose of his property and labor only as he consents. ${ }^{37}$ As the liberal sees it, however, liberty is not the only end of the legal system. Other goals must be considered in resolving conflicts among particular liberties, and in certain situations the law may give such goals higher priority than liberty. ${ }^{38}$

Consider the situation in which $A$ 's liberty to do $\mathrm{x}$ is incompatible with $B$ 's liberty to do $y$. The legal system must rank these conflicting liberties,

34. As the term is used here, a liberal is one who assigns a high value to personal liberty. Liberal theories share certain core concepts: government should be neutral as to what constitutes the good life, treating with equal respect each individual's self-chosen ends; government should guarantee the conditions necessary for the development and exercise of personal autonomy, leaving each individual free to pursue his own life plan as long as he allows others a similar freedom. See B. ACKERMAN, SOCLIL JUSTICE IN THE LIBERAL STATE 10-12, 346-48 (1980); R. DWORKIN, TAKING RIGHTS SERIOUSLY 272-73 (1977); C. FRIED, CONTRACT AS PROMISE 7 (1981); Dworkin, Liberalism, in PUBLIC AND PRIVATE MORALITY 113, 127 (S. Hampshire ed. 1978); Richards, Rights and Autonomy, 92 ETHICS $3,6-9,17$ (1981). Liberals disagree as to the conditions necessary for personal autonomy and thus disagree over the proper extent of governmental intervention. Libertarian liberals oppose governmental coercion except when necessary to protect citizens from forceful or fraudulent aggression against person or property; extensive inequality of wealth is justified as long as it results from transactions involving mutual consent. See, e.g., J. LOCKE, Second Treatise of Civil Government, in TREATISE OF GIVIL GOVERNMENT AND A LETTER CONCERNING TOLERATION (C. Sherman ed. 1937); R. NOZICK, ANARCHY, STATE, AND UTOPIA (1974). Egalitarian liberals, on the other hand, believe that some rough equality of economic resources and opportunities is necessary for personal autonomy; they thus favor considerable state intervention in economic relationships and substantial redistribution of wealth. See, e.g., C. BECKER, MODERN DEMOCRACY (1941); Dworkin, Liberalism, supra, at 128-33; Reiman, The Fallacy of Libertarian Capitalism, 92 ETHICs 85 (1981).

35. As the term is used here, "liberty" is the absence of deliberate forceful interference in the affairs of one person by another. See I. BERLIN, FOUR ESSAYS ON LIBERTY 122 (1969); J. FEINBERG, SOCIAL PHILOSOPHY 7 (1973). Liberals argue that liberty should be protected whenever doing so does not frustrate the pursuit of values with higher priority. Whenever one loses some liberty, one loses something of value. See M. BAYLES, PRINCIPLES OF LEGISLATION 78 (1978); J. FEINBERG, supra, at 21.

36. According to Locke, the purpose of law "is . . . to preserve and enlarge freedom. For . . . where there is no law there is no freedom. For liberty is to be free from restraint and violence from others; which cannot be where there is no law ... . ." J. LOCKE, supra note 34, \& 57, at 36-37.

37. This notion is expressed in Nozick's maxim of justice in transfers: "From each as they choose, to each as they are chosen." R. Nozick, supra note 34, at 160.

38. Liberals disagree as to which goals, if any, take priority over liberty. For purposes of my argument, however, it is not necessary to resolve this issue. 
assigning priority by weighing all the interests involved, not just the interest in liberty. If it is decided that $B$ 's liberty to do $y$ has priority, the legal system will coerce $A$, depriving him of his liberty to do $\mathrm{x}$, in order to protect $B$ 's liberty to do $y$. Liberties that get priority are called legal "rights"; conduct that is an interference with such a right is a legal "wrong." Coercion by the legal system, in the form of a court judgment that can be enforced by state action, is an interference with the liberty of one of the parties, but is justified, under the liberal view, if it protects a higher-priority liberty of the other party..$^{39}$

In the original hypothetical involving Contractor and Owner, Contractor's liberty to dispose of his property and labor only as he consents is incompatible with Owner's liberty to perform or breach the contract as she pleases. Contractor has consented to build a house on the condition that Owner pay him $\$ 50,000$. Contractor has not consented to any other transfer of property or labor. When Owner obtains part of a house from Contractor and pays nothing for it, she forces Contractor into a transfer to which he never consented. Owner's breach is a harmful interference with Contractor's liberty.

Contractor's liberty is given priority over Owner's liberty because Owner's breach not only causes a private harm to Contractor, but also causes a public harm: it makes Contractor, and others who learn of Owner's breach, less willing to enter into contracts and thus impairs the social practice of contracting for mutually beneficial exchange. Protecting Contractor's liberty entails state interference with Owner's liberty (a private harm) but does not cause any public harm; it reinforces, rather than impairs, the social practice of contracting. Thus, the liberal legal system recognizes Owner's breach as a legal wrong and imposes on Owner some form of liability designed to rectify her interference with Contractor's liberty.

The goal of protecting liberty, however, acts as a constraint on the liability imposed by a liberal system. In protecting $B$ 's liberty (or some other interest of $B$ ), the legal system should interfere with $A$ 's liberty only to the extent necessary to rectify $A$ 's harmful interference with $B$ 's liberty and to realize any other purpose for giving $B$ 's interests priority over $A$ 's. This principle will be referred to as the "Principle of Minimal Coercion."

39. See J. FEINBERG, supra note 35, at 23-24; A. GEWIRTH, REASON AND MORALITY 326-27 (1978); I. KANT, THE METAPHYSIGAL ELEMENTS OF JUSTICE 35-36 (J. Ladd trans. 1965).

40. The Principle of Minimial Coercion is derived from the notion that any particular liberty is valuable, supra note 35 , and thus should be infringed only to the extent necessary to promote higherpriority liberties or other higher-priority values. In our hypothetical, Owner's liberty to breach has a lower priority than the combination of Contractor's liberty and the need to reinforce the social practice of contracting. But Owner's liability should not exceed the amount necessary to realize these higher-priority values. 


\section{B. Measuring Liability: The Principle of Causal Responsibility}

Defendant's harmful interference with plaintiff's liberty can be rectified by making defendant liable for a sum that compensates plaintiff for the harm caused by defendant's interference. This suggests that when breach of contract is a harmful interference with liberty, the breaching party should be liable only for harm caused by her breach. ${ }^{41}$ Reinforcing the social practice of contracting, however, may require supercompensatory ${ }^{42}$ liability to adequately deter contract breaches. ${ }^{43}$

Deterrence provides the only legitimate reason for making the breaching party's liability exceed the amount needed to compensate plaintiff for the harm done. In particular, deterrence provides the only legitimate reason for making the breaching party compensate plaintiff for losses not caused by the breach. Even if some other goal (equality, for example) were given priority over liberty, that other goal could not justify making a defendant liable (as a defendant) for a loss she had not caused. There may be good reasons to make the defendant (as a participant in a social practice) bear part of such a loss, but even then, that loss would not be allocated by means of contract law or other rectifying law such as tort or restitution. Instead, the legal system should use some broader redistributive scheme that considers a large number of citizens as potential losssharers. ${ }^{44}$ If $A$ has not caused $B$ 's loss, a good reason is required for mak-

The notion that the legal system should minimize coercion is prevalent in liberal theory. See, e.g., F. HAYEK, THE CONSTITUTION OF LIBERTY 20-21, 133-47 (1960); J. LOCKE, supra note 34, § 159, at 108-09; J.S. MILL, ON LIBERTY 116 (C. Shields ed. 1956); R. TAYLOR, FREEDOM, ANARCHY, AND THE LAW 61 (1973).

41. It has been observed that "causal connexion is very generally required as a ground of liability." H.L.A. HART \& A.M. HONORE, CAUSATION IN THE LAW 125 (1959). In tort law, even those who advocate replacing negligence liability with strict liability would limit the defendant's liability to harms she has caused. See Epstein, A Theory of Strict Liability, 2 J. LEGAL STUD. 151, 203-04 (1973).

Nozick suggests that rectification of a transfer effected without the transferor's consent presumably requires both an estimate about what would have happened had the injustice not taken place and an attempt to realize such an outcome. $R$. Nozick, supra note 34 , at 152-53. This suggests that a defendant should be forced to pay plaintiff only enough to compensate plaintiff for the harm caused by defendant's wrong.

42. By "supercompensatory," I mean liability exceeding what is necessary to compensate plaintiff for harm caused by defendant's wrong.

43. The need to deter breach of contract is also implicit in the legal system's goal of protecting personal liberty. Many breaches involve harmful interference with the aggrieved party's liberty.

44. Aristotle's distinction between distributive justice and rectificatory justice is relevant and helpful. Distributive justice involves the distribution of honors and wealth among all citizens according to their relative deserts. ARISTOTLE, NichOMACHEAN ETHICS 117-20 (bk. V, chs. 2, 3) (M. Ostwald trans. 1962). In contrast, the concept of rectificatory justice applies to private transactions. In remedying an involuntary and unjust transfer, the judge should rectify the consequences of the wrong. Id. at 120-23 (bk. V, ch. 4). If $D$ has breached a contract partially performed by $P$ (as in our ContractorOwner hypothetical), Artistotle's notion of rectificatory justice seems to call for rectification of $P$ 's involuntary transfer; $D$ should be liable for $P$ 's loss caused by the breach. $P$ might be entitled to compensation for other losses as a matter of distributive justice (depending upon how "desert" is defined), but the burden of any such redistribution would presumably be shared by all (or at least 
ing $A$ bear part of that loss, some reason other than causal responsibility. Whatever that reason, it undoubtedly would apply to other citizens as well. Making $A$ liable for a loss she has not caused is unjustly discriminatory; it imposes the entire loss on only one of the many persons who ought to bear it. ${ }^{45}$

Nor is supercompensatory liability justified as an attempt to prevent unjust enrichment. Unjust enrichment is enrichment at another person's expense, enrichment through another person's loss. ${ }^{46} D$ 's enrichment is unjust only to the extent that it involves $P$ 's unjust deprivation, that is, only to the extent that $D$ obtains something to which $P$ is entitled by virtue of a better claim. If $D$ wrongfully appropriates $P$ 's property, $D$ 's enrichment is unjust only to the extent of $P$ 's loss, and $D$ 's liability should not exceed the amount needed to compensate $P$ for that loss. ${ }^{47}$

The liberal Principle of Minimal Coercion thus leads to the following conclusion: Defendant's liability should not exceed the harm caused by her wrong, unless greater liability is required for purposes of deterrence. This conclusion will be referred to as the "Principle of Causal Responsibility." In the liberal view, it applies whenever defendant's wrongful interference with plaintiff's liberty leads the legal system to interfere with defendant's liberty, forcing her to do something she has not consented to do. ${ }^{48}$

many) citizens.

45. See C. FRIED, supra note 34, at 103-06 (arguing that unconscionability doctrine should not be used to impose redistributive burdens on those who happen to contract with persons poorer than themselves); Kronman, Contract Law and Distributive Justice, 89 YALE L.J. 472, 502-03 (1980) (evaluating relative merits of taxation and regulation of contracts by extent to which they "consider how broadly the burdens of redistribution are spread").

46. J. DAWSON, UNJUST ENRICHMENT 3, 5, 6, 8, 150-51 (1951); RESTATEMENT OF RESTITUTION \$ 1 \& comment c (1936); Dawson, Restitution Without Enrichment, 61 B.U.L. REV. 563, 565, 620, 621 (1981); Dawson, Restitution or Damages?, 20 OHIO ST. L.J. 175, 176-77 (1959).

47. Assume that the market value of the property in $P$ 's hands was $\$ 10,000$, and that $D$ in some way converts it into property having a market value of $\$ 20,000$. Any increase in value is either (i) attributable to the appropriated property itself and to opportunities available to $P$ had he not been deprived of the property, or (ii) attributable to $D^{\prime}$ 's effort and skill and to opportunities not available to $P$ had he been allowed to retain the property. See D. DoBBS, supra note $8, \S 4.3$, at $242-44, \S 4.5$, at 273; RESTATEMENT OF RESTITUTION $\S 151$ comment c, $\S 154$ comment a (1936). $P$ has been unjustly deprived of $\$ 10,000$ plus whatever portion of the increased value falls within category (i). This is the amount of $D^{\prime}$ s unjust enrichment. It is no coincidence that this is also the amount required to compensate $P$ for his lost property and his lost opportunities, his losses caused by $D$ 's wrong. If $P$ recovers any portion of the increase falling within category (ii), it is not on the ground of unjust enrichment; such a supercompensatory recovery can be justified only by the need for deterrence.

It is often said that restitution deprives defendant of her unjust enrichment and thus sometimes gives plaintiff more than he had lost. This view seems to assume that plaintiff lost only the market value as of the time of defendant's misappropriation; it seems to ignore the possibility that restitution also compensates plaintiff for opportunities lost because of defendant's misappropriation.

In the Restatement of Restitution, a policy of deterrence lies behind the use of different rules for conscious wrongdoers and innocent defendants and the imposition of supercompensatory liability upon the former. See RESTATEMENT OF RESTITUTION $\$ 202$ comment c, $\$ 203$ comment a (1936).

48. The Principle of Causal Responsibility is so widely accepted that we seldom bother to state it, much less defend it. The principle can be found in Locke's discussion of the natural law that "no one 


\section{Measuring Liability: The Principle of Consent}

The Principle of Causal Responsibility limits liability when the legal system coerces a defendant to do something she has not consented to do. It does not, however, apply when the legal system forces a defendant to do something she has previously consented to do, at least not where the prior consent was contractual. ${ }^{49}$

The liberal view not only recognizes contractual consent, it regards it as irrevocably binding. In the social practice of contracting, promissory consent involves a commitment to put some portion of one's resources at the disposal of the promisee at some specified time. Such consent is treated as irrevocable because it induces expectation and reliance. The efficacy of the social practice depends upon the irrevocability of consent. ${ }^{50}$

We thus arrive at the following liberal principle: The legal system does not interfere with a defendant's liberty if the liability imposed on a defendant forces her to do something she has contractually consented to do. ${ }^{\text {sI }}$ This principle will be referred to as the "Principle of Consent." When the Principle of Consent applies, the Principle of Causal Responsibility does

ought to harm another in his life, health, liberty, or possessions." J. LOCKE, supra note $34, \S 6$, at 6 . Those who transgress this law may be punished only to the degree necessary for "reparation" (satisfaction or compensation for the harm suffered) and "restraint" (hindrance or deterrence of such violations). Id. $\$ \S 7-10$, at 7-9. "For these two are the only reasons why one man may lawfully do harm to another." Id. $\S 8$, at 7 .

49. A liberal legal system seeks to protect personal liberty from harmful interference, but it also permits cooperative interaction among persons. To distinguish cooperative interaction from interference with liberty, liberals employ the notion of consent. When $A$ takes $B$ 's lawnmower from $B$ 's garage and uses it to cut his own grass, $A$ does not interfere with $B$ 's liberty if $B$ has consented to $A$ 's use of the lawnmower. Without some notion of consent as a defense, any use of another person's resources would run the risk of being declared a legal wrong, unless there were an extensive (and excessively rigid) set of rules specifying wrongful uses. Such a scheme would not be very conducive to cooperative interaction. It is more convenient to stipulate that $A$ does not interfere with $B$ 's liberty when $A$ does something with $B$ 's consent. $B$ 's consent thus negates $A$ 's tort. $C f$. W. PROSSER, HANDBOOK OF THE LAW OF TORTS $\S 18$, at 101 (4th ed. 1971) (describing tort doctrine of volenti non fit injuria-to one who is willing, no wrong is done).

50. Thus, if $D$ on May 1 contractually consents to pay $P \$ 1000$ on November 1 , and then on November 1 refuses to pay, her May consent remains operative despite the November repudiation. When the legal system forces $D$ to pay $P$ the $\$ 1000$, it does not, according to the liberal, interfere with $D^{\prime}$ s liberty because it is taking $D^{\prime}$ 's money with her consent. Indeed, there is only an illusion of consent if the commitment is revocable. "For to consent to be tied no further than a person agrees to at some future time is not to consent to anything at all." P. ATIYAH, THE RISE AND FALL OF FREEDOM OF CONTRACT 51 (1979) (summarizing Locke's notion of consent).

51. An exception may be appropriate when defendant has contracted to perform personal services and a specific performance decree is regarded as an undue interference with her liberty. We need not resolve this issue, however, for purposes of this Article, which deals only with restitution of money or specific property.

A Kantian version of the principle stated in the text is presented in C. FRIED, supra note 34, at 1314, 18-21. Fried suggests that the legal system must enforce defendant's contractual consent in order to treat her as a free and rational person and enhance her freedom by giving her will the greatest possible range consistent with the will of others. But see B. ACKERMAN, supra note 34, at 196-99 (suggesting that no convincing argument can be made for the view that contractual consent is always binding). 
not come into play; the latter principle limits liability only when the legal system interferes with a defendant's liberty.

\section{Liberal Liability Principles and Buyer's Breach When the Seller Has Partially Performed}

Let us now apply these liberal principles of liability in the hypothetical involving Contractor and Owner. Owner's breach subjected Contractor to an involuntary transfer of property and labor. If Owner had agreed to pay a price for Contractor's partial performance, Owner could be held liable for that price under the Principle of Consent and coercion would therefore not be necessary. But Owner has not agreed to pay any particular price for Contractor's partial performance. Owner agreed to pay $\$ 50,000$ for a complete house, not $\$ 40,000$ (or any other amount) for four-fifths of a house. Under the liberal view, the legal system may justifiably coerce Owner to protect Contractor's higher-priority liberty. It is not feasible for Owner to return Contractor's partial performance in specie, and so Owner must be liable for an amount she has not previously consented to pay. There must therefore be a forced exchange, an interference with Owner's liberty.

The Principle of Causal Responsibility then comes into play. Upon Owner's breach, Contractor has a net loss of $\$ 48,000$ (Contractor's costs incurred in part performance for which he has been paid nothing). If Owner had performed, Contractor would have incurred a net loss of $\$ 10,000$ (the difference between his $\$ 60,000$ total costs and the $\$ 50,000$ contract price). Owner's breach has therefore caused a loss of $\$ 38,000$. The remaining $\$ 10,000$ loss would have occurred in the absence of any breach; Owner's breach was not a cause of the loss because it was not a necessary condition for that loss. ${ }^{52}$ Thus, under the liberal view, Owner's

52. A wrongful act or omission is not a legal cause of a loss if it is not a necessary condition for that loss. See D. DOBBS, supra note $8, \S 3.3$, at $148-50$; W. Prosser, supra note $49, \S 41$. $A$ is a necessary condition for $B$ if $A$ is a member of the set of conditions that actually occurred and that were individually necessary and jointly sufficient for $B$. See Taylor, Causation, in 2 ENCYCLOPEDIA OF PHILOSOPHY 56, 62-63 (1967). Thus, $A$ is a necesssary condition for $B$ if $B$ would not have occurred in the absence of $A$, given the conditions that did exist and ignoring conditions that did not exist. $A$ necessary condition may be referred to as a "necessary cause" or a "but for cause" or a "cause in fact" or a "cause sine qua non."

A legal cause ("proximate cause" or "responsible cause") is a human act or omission that is a necessary condition and that is distinguishable from other necessary conditions by virtue of being conspicuously relevant to the policy purpose of the inquiry as to causation and responsibility. See H.L.A. HART \& A.M. HONORÉ, supra note 41, 79-102, 104; W. PROSSER, supra note 49, § 42. We need not deal with the perplexing question of what constitutes legal cause, since a breach of contract cannot be a legal cause of a loss if it is not even a necessary condition for that loss.

There are exceptional situations in which a legal cause is not a necessary condition. These situations involve two concurrent causes, each of which would have been sufficient to produce the harm in the absence of the other (for example, two men simultaneously fire bullets into their victim's brain). See D. DOBBS, supra note 8, § 3.3, at 149-50; H.L.A. HART \& A.M. HONORÉ, supra note 41, at 116- 
liability should not exceed the $\$ 38,000$ expectancy damages, unless greater liability is required for purposes of deterrence.

Assume, for the sake of argument, that expectancy damages do not provide adequate deterrence to breach. Perhaps the general deterrence level is too low; that is, too few contracts are performed and too many are breached. There may also be specific types of breach (for example, breaches that threaten to drive the aggrieved party out of business) that call for greater deterrence than expectancy damages provide. The availability of restitution as an optional remedy for breach provides additional deterrence in situations in which restitutionary liability exceeds expectancy damages. But restitution seems an inappropriate method for achieving the desired deterrence.

First, the additional deterrence achieved by giving plaintiff a choice between expectancy damages and market value restitution is slight. ${ }^{\text {ss }} \mathrm{Mar}$ ket value restitution affords additional deterrence only when buyer knows that the market value of seller's partial performance will exceed seller's expectancy damages for breach. This is probably met only in a small fraction of the transactions that require greater deterrence against breach.

Second, market value restitution will almost always either overdeter or underdeter. The market value of seller's partial performance is unrelated to the level of liability needed to effect optimal deterrence (whatever that level is). Only as a rare coincidence will market value restitution impose liability at or near the optimal level for deterrence.

If expectancy damages do not provide adequate deterrence, punitive damages offer a better corrective than does restitution. Indeed, deterrence is a principal purpose of punitive damages. ${ }^{54}$ Unlike restitution, punitive damages can be tailored to produce a given level of deterrence. Although courts have been reluctant to award punitive damages in breach of contract actions, there is a recent trend toward a more liberal and flexible use of this remedy. ${ }^{\mathrm{s}}$

19, 216-25; W. PROSSER, supra note 49, $\S 41$, at 239-40. Owner's breach of contract, however, is not such a cause with respect to Contractor's $\$ 10,000$ loss. Although that loss would have occurred even if the contract had been performed, we cannot say that Owner's breach would have been sufficient to cause that loss in the absence of Contractor's underestimation of his costs.

53. I assume that restitution would be measured by the market value of seller's partial performance; this is the measure favored by the courts. See supra p. 18. As a deterrent, each of the other measures of monetary restitution suffers from the same defects: additional deterrence is provided only when restitutionary liability exceeds expectancy damages, and restitution usually overdeters or underdeters.

54. See, e.g., Miller v. Elite Ins. Co., 100 Cal. App. 3d 739, 759-60, 161 Cal. Rptr. 322, 333-34 (1980); Traylor v. Wachter, 227 Kan. 221, 224, 607 P.2d 1094, 1098 (1980); Coryell v. Colbaugh, 1 N.J.L. 77 (Sup. Ct. 1791); Terry v. Zions Coop. Mercantile Inst., 605 P.2d 314, 328 (Utah 1979); C. MCCORMICK, HANDBOOK ON THE LAW OF DAMAGES $\S 77$, at 275-76 (1935); Note, Punitive Damages in Contract Actions-Are the Exceptions Swallowing the Rule?, 20 WASHBURN L.J. 86, 88 (1980).

55. See, e.g., Gruenberg v. Aetna Ins. Co., 9 Cal. 3d 566, 578-81, 510 P.2d 1032, 1040-42, 108 
We must conclude that, under the liberal view, money restitution should be abandoned as a remedy for breach of contract when plaintiff is a seller who has partially performed; such a plaintiff should be limited to his expectancy damages. ${ }^{56}$ Restitition either violates the Principle of Causal Responsibility (when the restitutionary award exceeds plaintiff's expectancy damages) or is an unnecessary remedy (when the restitutionary amount does not exceed plaintiff's expectancy damages).

\section{Liberal Principles in the Law of Restitution}

Courts grant restitution in a variety of situations, some of which do not involve breach of contract. A survey of the case law of restitution reveals a general pattern consistent with the liberal principles discussed above and highlights the anomaly of money restitution in the case of the partially performing seller when buyer has breached.

\section{A. Restitution as a Remedy for Breach of Contract When Plaintiff Is a Buyer}

If plaintiff is a buyer who has paid all or part of the contract price when the seller breaches, plaintiff recovers his money, even if this makes him better off than contract performance would have. ${ }^{87}$ Although defendant may be forced to pay more than would be necessary to compensate plaintiff for losses caused by her breach, full restitution of plaintiff's payment is justified by the Principle of Consent: the legal system does not interfere with defendant's liberty when it forces her to do something she has contractually consented to do. When the contract was formed, plaintiff buyer agreed to pay the contract price only on the condition (implied, if not expressed) that seller deliver the specified property or services. In accepting these terms, defendant seller agreed not to keep buyer's money if

Cal. Rptr. 480, 488-90 (1973); Boise Dodge, Inc. v. Clark, 92 Idaho 902, 907, 453 P.2d 551, 556 (1969); Vernon Fire \& Casualty Ins. Co. v. Sharp, 316 N.E.2d 381 (Ind. Ct. App. 1974), modified on other grounds, 349 N.E.2d 173 (Ind. 1976); Holmes, Is There Life After Gilmore's Death of Contract?-Inductions from a Study of Commercial Good Faith in First-Party Insurance Contracts, 65 CORnell L. REV. 330 (1980); Sullivan, Punitive Damages in the Law of Contract: The Reality and the Illusion of Legal Change, 61 MINN. L. REV. 207 (1977); Note, supra note 54.

56. Expectancy damages are not fully compensatory inasmuch as they do not compensate plaintiff for litigation expenses and other transaction costs incurred as a result of defendant's breach. See supra p. 24. Such compensation could be awarded by expanding the scope of expectancy damages or by utilizing punitive damages. Either method would be preferable to restitution, which provides compensation only as a rare coincidence.

57. See supra note 4. Assume that buyer has agreed to pay a contract price of $\$ 10,000$ and has already paid this amount when seller breaches. Seller has not delivered any of the property or services contracted for. At the time of seller's breach, the market price has dropped to $\$ 5000$. Full restitution of buyer's $\$ 10,000$ payment enables buyer to obtain for $\$ 5000$ something for which he had contracted to pay $\$ 10,000$. 
she could not deliver the specified property or services. ${ }^{58}$

\section{B. Restitution as a Remedy for Breach of Contract When Plaintiff Is a Seller}

If a plaintiff seller has partially performed when buyer breaches, and the partial performance can be returned in specie, the court may award specific restitution. ${ }^{59}$ Specific restitution on behalf of a seller plaintiff is similar to restitution of money paid by a buyer plaintiff. In both cases, the restitution rectifies an involuntary transfer and is justified under the Principle of Consent. ${ }^{00}$

If plaintiff seller has completely performed, and defendant buyer owes only a liquidated debt, plaintiff cannot obtain restitution as a remedy for defendant's breach. ${ }^{61}$ Plaintiff is limited to an action for the unpaid contract price and can therefore recover only his expectancy. Money restitution exceeding the contract price would violate the Principle of Causal Responsibility by interfering with defendant's liberty beyond the extent necessary to compensate plaintiff for loss caused by the breach. ${ }^{62}$ Such restitution would not be justified by the Principle of Consent (as an action for the price would be), because it would force defendant to pay more than she had contractually consented to pay.

Courts fashion only one restitutionary remedy for buyer's breach that is inconsistent with liberal principles: money value restitution in the case of a partially performing seller. As explained above, this remedy is not justified under the Principle of Consent and it violates the Principle of Causal Responsibility.

\section{G. Restitution in Favor of a Party in Breach of Contract}

The courts are divided on the question of whether, and how much, restitution should be granted for partial performance by a party in breach of contract. For example, in construction contract cases, if the contractor

58. I have assumed that plaintiff buyer has not received any performance from seller. If buyer has received some performance, he must return it (or its value) to obtain restitution of his money payment. See supra note 2.

59. See supra note 6 .

60. The seller plaintiff has agreed to deliver certain property only on the condition that buyer pay the contract price; seller has not agreed to deliver part of his performance for nothing. In accepting seller's terms, buyer has agreed not to keep seller's performance while paying nothing in return.

61. See supra note 5 .

62. Specific restitution would be permitted under the Principle of Consent, but it is not normally granted when seller has fully performed. The full performance rule, however, may not always be the reason for denying specific restitution. For example, courts may be reluctant to make a fee simple defeasible or provide a security interest not bargained for. 1 G. PALMER, supra note $2,84.3$, at 383$84, \S 4.7(\mathrm{a}), \S 4.16$, at $499-500, \S 4.19$. 
has committed a material breach, ${ }^{63}$ and the owner is not in breach, some courts deny restitution altogether, ${ }^{64}$ thereby subjecting the contractor to an involuntary transfer of property and labor. This result is inconsistent with liberal principles. Total forfeiture violates the Principle of Minimal Coercion because it interferes with the contractor's liberty beyond the point necessary to protect the owner's expectancy.

Some courts grant restitution, awarding the breaching contractor the lesser of two amounts: (i) the unpaid contract price minus owner's damages for breach; or (ii) the net increase in owner's wealth attributed to contractor's partial performance. ${ }^{65}$ Limiting contractor's restitution to the unpaid contract price minus owner's damages for breach ensures that Owner at least gets her expectancy. Owner obtains more than her expectancy, however, if the net increase in her wealth is less than the unpaid contract price minus her damages for breach. This seems inconsistent with the Principle of Minimal Coercion, since contractor may be subjected to an involuntary transfer exceeding that necessary to protect owner's expectancy.

Some courts have measured the breaching contractor's restitution without any ceiling imposed by owner's net gain; the contractor simply recovers the unpaid contract price minus owner's damages for breach. ${ }^{86}$ Such a remedy ensures that the owner obtains her expectancy, but it may force the owner to pay restitution exceeding the amount necessary to rectify contractor's involuntary transfer, a violation of the Principle of Minimal Coercion. ${ }^{67}$

The Principle of Minimal Coercion seems to require restitution in an

63. If the breach is not "material" and the contractor has thus "substantially" performed, he cannot obtain restitution. He is subject to the rule that precludes a fully performing seller from obtaining restitution when buyer owes only a liquidated sum of money. Id. $\S 5.2$. The Contractor, however, may enforce the contract and recover the unpaid contract price minus owner's damages for breach. Id. \$§ 5.2, 5.14(a).

64. See, e.g., Miller v. Yockey, 49 Colo. 303, 112 P. 772 (1911); Faxon v. Mansfield, 2 Mass. 147 (1806).

65. See, e.g., United States ex rel. Arlmont Air Condition Corp. v. Premier Contractors, Inc., 283 F. Supp. 343 (D. Me. 1968); 1 G. PALMER, supra note 2, \$§ 5.3, 5.14(e); RESTATEMENT, supra note $1, \S 357$ illustration 3 .

66. See, e.g., Pinches v. Swedish Evangelical Lutheran Church, 55 Conn. 183, 10 A. 264 (1887); Blakeslee v. Holt, 42 Conn. 226, 229 (1875).

67. Assume the following. The contract price is $\$ 100,000$. Contractor partially performs and then breaches. He has incurred costs of $\$ 45,000$ in partial performance; full performance would have cost him an additional $\$ 45,000$. Owner pays another contractor $\$ 40,000$ to complete the structure; the completed structure enhances the market value of owner's real estate by $\$ 80,000$.

If owner pays restitution of $\$ 60,000$ ( $\$ 100,000$ unpaid contract price minus $\$ 40,000$ damages for breach), owner obtains her expectancy (she has the complete structure for a total cost of $\$ 100,000$ ), but she has paid contractor more than enough to prevent contractor's involuntary transfer. Contractor voluntarily agreed to transfer his labor and property for compensation that would yield a $\$ 10,000$ net profit. If he receives restitution of $\$ 60,000$, he obtains a net profit of $\$ 15,000$ (despite the fact that he has only partially performed). 
amount equal to the lesser of (i) a pro rata portion of the contract price, using the ratio that contractor's incurred costs bear to his costs for full performance, (ii) the amount that gives contractor his expectancy, and (iii) the amount that leaves owner with her expectancy. ${ }^{68}$ Because of the need to reinforce the social practice of contracting, owner's right to obtain her expectancy takes priority over the breaching contractor's desire to avoid an involuntary transfer. As long as owner obtains her expectancy, contractor should be compensated for partial performance at the contract rate, the rate at which contractor agreed to transfer his labor and property and thus the compensatory rate at which the transfer might be regarded as voluntary. Contractor should not, under the liberal view, recover restitution that makes him better off than full performance would; if he agreed to an exchange that would have left him with a net loss, that loss should be regarded as voluntary.

\section{Restitution When Performance of a Contract Is Excused by Impossi- bility, Impracticability, or Frustration of Purpose}

If one party is excused from performance of a contract on the ground of impossibility, impracticability, or frustration of purpose, both parties are discharged from any duty of further performance, and any partial performance by either party is "restored" by way of restitution. ${ }^{60}$ In measuring money restitution for a partially performing seller, the prevailing practice is to make use of the contract terms and award a pro rata portion of the contract price, using the ratio that the value of seller's partial performance bears to the value of his promised performance. ${ }^{20}$ This compensates the seller at the agreed upon exchange rate; it thus gives him the advantage (or disadvantage) of his bargain, but only for the portion of the contract that has been performed.

Restitution measured by the pro rata formula is consistent with the Principle of Minimal Coercion. Some restitution is necessary to avoid seller's involuntary transfer of wealth. ${ }^{71}$ Assuming that seller is the party

68. In the hypothetical presented supra note 67 , restitution of $\$ 50,000$ would give contractor the pro rata portion of the contract price he has earned on the basis of costs incurred. Restitution of $\$ 55,000$ would give contractor his expectancy (assuming that his breach did not enable contractor to redirect his resources to another revenue-producing project). Restitution of $\$ 60,000$ leaves owner with her expectancy. Under the method proposed in the text, owner should pay the breaching contractor $\$ 50,000$.

69. E.g., Butterfield v. Byron, 153 Mass. 517, 27 N.E. 667 (1891); Wolfe v. Howes, 20 N.Y. 197 (1859); 2 G. PALMER, supra note $2, \S 7.1$.

70. E.g., Dame v. Wood, 75 N.H. 38, 70 A. 1081 (1908); Weis v. Devlin, 67 Tex. 507, 3 S.W. 726 (1887); 2 G. PALMER, supra note 2, §§ 7.5, 7.7(a), 7.8(b); see U.C.C. \$§ 2-607(1), 2-613(b) (1977).

71. Pro rata restitution is designed to prevent unjust deprivation and not unjust enrichment. See Dawson, Restitution Without Enrichment, supra note 46, at 585-92. The amount of restitution is not measured by the net increase in buyer's wealth, but by the value seller has lost (measured at the rate 
excused by reason of intervening burden, the need to relieve seller from this burden overcomes the need to protect buyer's expectancy and justifies giving the seller something better than his expectancy. Assuming that seller's partial performance cannot be returned in specie, it is thus proper, under liberal principles, to measure seller's restitution by the contract rate derived from the valid consensual agreement of the parties. ${ }^{72}$ Although pro rata restitution imposes a forced exchange upon the buyer (who never consented to pay a particular price for partial performance), it comes close to the parties' contractual consent and therefore minimizes the extent to which either party is coerced. The innocent buyer is not assured of obtaining her expectancy (as she would be if seller were in breach); nonetheless, she may not suffer a net loss. ${ }^{73}$

\section{E. Restitution When a Contract Is Unenforceable Under the Statute of Frauds}

When an oral contract is unenforceable because of the statute of frauds, a party who has rendered some performance and has not breached the contract ${ }^{74}$ can obtain restitution. ${ }^{75}$ Restoration of money paid by a buyer and specific restitution of property delivered by a seller are consistent with the Principle of Consent; the recipient has undoubtedly agreed not to retain such benefits if she fails to perform her side of the bargain.

If plaintiff's performance involves services or nonreturnable property, the usual measure of money restitution is the market value of plaintiff's bargained-for performance. ${ }^{76}$ I have suggested that, under the liberal

at which seller consented to part with his labor and property).

72. Valid contracts must be distinguished from agreements held voidable for fraud, duress, or mistake. When a contract is not tainted by any defect in the bargaining process, its terms, under the liberal view, should control the restitutionary adjustment to the extent possible.

73. If buyer's benefit from seller's partial performance is exceeded by the pro rata restitution she pays, such restitution will subject her to a net loss. In such a situation, pro rata restitution seems inconsistent with the Principle of Minimal Coercion (it is difficult to justify coercion that merely shifts a loss from one innocent party to another), unless the contractual agreement assigned the risk of such loss to the buyer.

74. The majority view is that a party who has breached the oral contract cannot obtain restitution for his partial performance. See, e.g., Watkins v. Wells, 303 Ky. 728, 730, 198 S.W.2d 662, 663 (1946); Mack v. Bragg, 30 Vt. 571, 572 (1858); J. CALAMARI \& J. PERILlo, supra note 1, \$19-41; 2 A. CORBIN, supra note $1, \S 332 ; 2$ G. PALMER, supra note $2, \S 6.12(\mathrm{~b})$. This view is consistent with the rule that a party cannot obtain restitution if he is in material breach of an enforceable contract. See id. In states that award restitution to a party in breach of an enforceable contract, courts can be expected to award restitution to a party in breach of an unenforceable contract. Id.

75. E.g., Gilton v. Chapman, 217 Ark. 390, 391, 230 S.W.2d 37, 38 (1950); Wonsettler v. Lee, 40 Kan. 367, 369, 19 P. 862, 863 (1888); J. CALAMARI \& J. PERILlo, supra note 1, \$ 19-40; 2 A. CORBIN, supra note $1, \S \S 321,325,326 ; 2$ G. PALMER, supra note $2, \S 6.12(a)$; RESTATEMENT, supra note $1, \S 355$ \& comments $a, b$.

Under the Uniform Commercial Code, a contract that fails to satisfy the writing requirement is enforceable to the extent of plaintiff's performance. U.C.C. \$ 2-201(3)(c) (1977).

76. E.g., Bennett Leasing Co. v. Ellison, 15 Utah 2d 72, 75, 387 P.2d 246, 248 (1963); Cochran v. Bise, 197 Va. 483, 487-89, 90 S.E.2d 178, $181-82$ (1955); 2 G. PALMER, supra note 2, § 6.3(b); 
view, market value restitution is an improper remedy for breach of an enforceable contract because it violates the Principle of Causal Responsibility; the breaching party should be liable only for an amount that compensates the plaintiff for losses caused by the breach, and the remedy should thus be limited to plaintiff's expectancy damages. The same reasoning might seem applicable to market value restitution in favor of the nonbreaching party who has partially performed a contract unenforceable under the statute of frauds. But expectancy damages, or restitution based on the contract price or contract rate, would enforce the terms of the oral contract (at least to some extent) and thus frustrate the purpose of the statute of frauds. Given this controlling purpose, market value restitution is consistent with liberal principles. ${ }^{77}$

\section{F. Restitution When a Contract Is Unenforceable Because of Basic Mistake}

If party $A$ made a basic mistake when entering into a contract with $B{ }^{28}$ he may be allowed to avoid the contract if its performance would leave him substantially worse off than he anticipated when he made the contract. Although he has consented to the contract terms, $A$ has not consented to the adverse exchange of economic values thereby entailed. Thus, there is a reason to disregard $A$ 's consent and nullify the contract. But there is also a reason to enforce the contract, namely, to protect $B$ 's expectancy, thus reinforcing the social practice of contracting. ${ }^{79}$ In deciding

RESTATEMENT, supra note $1, \S 347$ \& comment c, § 355; RESTATEMENT (SECOND), supra note 1 , $\S$ 371 \& comments $a, b, \S \S 373,375$. Most judicial opinions use the term "reasonable value." The contemporary meaning of this term is "market value." E.g., Bennett Leasing Co., 15 Utah 2d at 7677, 387 P.2d at 249 (Henriod, C.J., dissenting); RESTATEMENT (SECOND), supra note 1, § 371 comment a.

77. A plaintiff seller who has partially performed an unenforceable contract has not consented to perform without compensation and thus deserves restitution that rectifies his involuntary transfer. The statute of frauds, on the other hand, is designed to avoid forcing defendant to make an involuntary transfer as a result of perjury and thus precludes remedies based on the terms of the alleged contract. Although market value restitution is likely to result in a forced exchange on terms to which neither party consented, it can be a reasonable compromise when the terms consented to cannot be enforced. Market value restitution is consistent with the Principle of Minimal Coercion because it coerces defendant only to the extent necessary to rectify plaintiff's involuntary transfer without frustrating the purpose of the statute of frauds.

78. "Mistake" is a state of mind not in accord with the facts. RESTATEMENT, supra note $1, \S 500$. A mistake is "basic" if it is a serious mistake concerning a fact that provides a basis for the bargain, so that the exchange required by the contract terms is substantially different from that presumed by the mistaken party. See 2 G. PALMER, supra note $2, \S 12.2$; RESTATEMENT OF RESTITUTION $\$ 9$ comment c, $\$ 16$ comment c (1936). See also RESTATEMENT (SECOND), supra note 1, §§ 152, 153 (discussing when mistake makes a contract voidable).

79. See 2 G. PALMER, supra note $2, \S 12.2$, at 533-34. If $A$ seeks to avoid a contract on the ground of basic mistake, and $B$ shared $A$ 's mistaken belief or assumption (a "mutual mistake"), enforcement of the contract is likely to give $B$ something better than she expected, for example a fertile rather than a barren cow, as in Sherwood v. Walker, 66 Mich. 568, 33 N.W. 919 (1887). This helps explain why relief for mutual mistake has been more readily granted than relief for unilateral mis- 
whether to grant relief on the ground of mistake, courts balance these competing concerns. ${ }^{80}$

If the contract is declared unenforceable, each party is entitled to restitution for any performance rendered to the other ${ }^{\mathbf{8 1}}$ The return of money paid by a buyer, or specific restitution of property delivered by a seller, restores both parties to their pre-contract positions and is consistent with the Principle of Minimal Coercion. Assuming that $A$ is the party who has partially performed, such restitution coerces $B$ only to the extent necessary to rectify $A$ 's involuntary transfer. Because she is restored to the status quo ante, $B$ suffers no harm as a result of $A$ 's mistaken contractual assent. Neither innocent party suffers a net loss.

If $A$ has delivered services or property that cannot be returned in specie, the measure of money restitution would presumably be the market value of $A$ 's partial performance. ${ }^{82}$ But when market value restitution would be required, a court is unlikely to permit $A$ to avoid the contract. ${ }^{33}$ Market value restitution subjects $B$ to a forced exchange and may require $B$ to pay more for $A$ 's partial performance than $B$ would have been willing to pay. If there is a serious risk that avoidance and restitution would leave $B$ worse off than before, the contract probably will be enforced. ${ }^{\mathbf{3 4}}$ Although the need to save $A$ from serious loss might outweigh the need to protect $B$ 's expectancy, it does not outweigh the need to protect $B$ against loss. There is no reason to shift loss from an innocent but mistaken party to an innocent party who made no mistake. Avoidance with restitution would therefore violate the Principle of Minimal Coercion because it would coercively subject $B$ to a harm not justified by any higher-priority interest of $A^{.85}$

take. See 2 G. PALMER, supra note $2, \S \S 12.1$, at 532, 12.3(c).

80. The need to balance such concerns is noted in J. CALAMARI \& J. PERILLO, supra note $1, \S 9-$ 25; 2 G. PALMER, supra note $2, \S 12.2$; RESTATEMENT (SECOND), supra note 1 , introductory note to ch. 6 , at $379-80$.

81. See, e.g., 2 G. PALMER, supra note $2, \S 12.6($ a); RESTATEMENT (SECOND), supra note $1, \S$ 158(1).

82. See, e.g., Tyra v. Cheney, 129 Minn. 428, 430, 152 N.W. 835, 835 (1915); RESTATEMENT (SECOND), supra note $1, \S 371$ \& comments $a, b, \S 376$ illustration 3 . Restitution should not be measured by the contract terms because the contract is tainted by a serious defect in the bargaining process (the mistake).

83. For example, after partial performance of a construction contract, a contractor will probably not be allowed to avoid the contract and obtain restitution because of his mistaken bid. 2 G. PALMER, supra note $2, \S 12.20$ (d).

84. It is often said that one party cannot ordinarily avoid a contract for mistake if the other party cannot be restored to the status quo ante. See, e.g., Grymes v. Sanders, 93 U.S. 55, 62 (1876); M.F. Kemper Constr. Co. v. City of Los Angeles, 37 Cal. 2d 696, 701, 235 P.2d 7, 10 (1951); Olson v. Shephard, 165 Minn. 433, 436, 206 N.W. 711, 712 (1926); 3 A. CORBIN, supra note 1, § 606, at 64950.

85. If $B$ knew (or should have known) at the time of contracting that $A$ 's assent was based on a serious mistake, relief for $A$ is likely, even though it requires market value restitution for $A$ 's performance. Tyra v. Cheney, 129 Minn. 428, 152 N.W. 835 (1915); 2 G. PALMER, supra note 2, §§ 12.3(a), 


\section{G. Restitution When a Contract Is Unenforceable Because of Fraud or Duress}

A person who has been induced into a contract by fraud may avoid the contract and obtain restitution for any performance rendered. ${ }^{86}$ The same rights are granted to a person coerced into a contract through duress. ${ }^{87}$ The victim of fraud or duress has suffered an interference with his freedom to dispose of his property only through informed and voluntary consent; in a liberal legal system, his assent to the contract is therefore invalid and the contract is unenforceable.

Restitution, like avoidance, protects the victim's autonomy; its purpose is to rectify the victim's involuntary transfer. ${ }^{88}$ In measuring restitution, the contract terms must be disregarded because fraud or duress is a fatal defect in the bargaining process. The victim is entitled to restitution of money paid, to specific restitution of property that can be returned, and probably to market value restitution for performance involving services or nonreturnable property; the victim must also restore any performance rendered by the other party. ${ }^{88}$

The measure of the victim's restitution, however, is regulated by an important principle. If the other party is guilty of duress or tortious fraud, she has wrongfully interfered with her victim's freedom of choice; restitution will be fashioned so as to ensure that the victim is fully restored to his pre-contract position and does not suffer any loss as a result of the wrongful interference with his liberty. For example, a defrauded vendor of land not only recovers the land but also the fair rental value for the duration of the purchaser's occupancy or the profits derived by the purchaser from her use of the land, whichever is greater. ${ }^{80}$

12.20(d), at 694; RESTATEMENT (SECOND), supra note 1, $\$ 153,376$ illustration 3. B's conduct is at worst fraudulent and at best careless. The need to enforce the contract to protect reasonable expectations disappears because $B$ 's expectations are not reasonable; $A$ thus deserves to be relieved from performance. Market value restitution is justified, even though it may involve harmful interference with $B$ 's liberty. Because of $B$ 's fraudulent or careless conduct, $A$ 's liberty (not to partially perform for nothing) has priority over $B$ 's liberty.

86. J. Calamari \& J. Perillo, supra note $1, \S 9-23 ; 1$ G. Palmer, supra note $2, \S \S 3.1,3.3$; RESTATEMENT (SECOND), supra note $1, \S \S 164,376$.

87. J. CALAMARI \& J. PERILLO, supra note 1, § 9-8; 2 G. PALMER, supra note 2, § 9.1, at 242-43; RESTATEMENT (SECOND), supra note 1, §§ 174-76, 376.

88. See, e.g., Earl v. Saks \& Co., 36 Cal. 2d 602, 611, 226 P.2d 340, 346 (1951); Brett v. Cooney, 75 Conn. 338, 53 A. 729 (1902).

89. 1. G. PALMER, supra note $2, \S \S 3.3,3.11$ (fraud); RESTATEMENT (SECOND), supra note 1, $\S$ 371 \& comments $a, b, \S \S 372,376,384$ (duress).

90. Lang v. Giraudo, 311 Mass. 132, 140, 40 N.E.2d 707, 711 (1942); 1 G. PALMER, supra note 2 2 $\S 3.15$ (a); RESTATEMENT OF RESTITUTION $\S 157$ \& comments a, d, illustration 3 (1936). This approach ensures that the vendor is compensated, as fully as possible, for economic opportunities lost as a result of the transfer. A defrauded purchaser of land, on the other hand, gets his money back, gives the land back, and pays the vendor the lesser of fair rental value or profits derived from his use of the land. Beaudry v. Favreau, 99 N.H. 444, 447-48, 114 A.2d 666, 668-69 (1955); 1 G. PALMER, supra note $2, \S 3.12$, at $303-04, \S 3.14(\mathrm{~b})$; RESTATEMENT OF RESTITUTION $\S \S 155,157$ comment $d$, 
In a liberal legal system, the victim of fraud or duress will not be allowed to suffer loss as a result of wrongful interference with his freedom to dispose of his property voluntarily. If the court cannot restore both parties to their pre-contract positions, the innocent victim will be fully restored at the expense of the party who has wrongfully interfered with his liberty. But the wrongdoer is coerced no more than is necessary to compensate the victim for the wrongful interference. The restitutionary remedy is thus consistent with the Principle of Causal Responsibility.

\section{H. Restitution for an Unsolicited Benefit Intentionally Conferred}

Restitution is not limited to contractual situations. A person might obtain restitution for a benefit conferred upon someone who has not contracted for or requested the benefit. Consider, first, situations in which $P$ knowingly and intentionally confers an unsolicited benefit upon $D$. Assuming that the benefit cannot be returned in specie, ${ }^{91} P$ is generally unable to obtain money restitution for a benefit intentionally conferred upon $D$ without $D$ 's request. Obligations to pay for benefits usually arise only through consent. If $P$ intended to make a gift to $D, P$ obviously is not entitled to restitution, since $P$ has not suffered any involuntary deprivation. ${ }^{92}$ If $P$ did not intend a gift, it is likely that he attempted to force $D$ into an exchange without benefit of contract. A liberal legal system will not permit such interference with $D$ 's freedom. If $P$ did not give $D$ an opportunity to reject the benefit, $P$ is likely to be regarded as an officious intermeddler and be denied restitution..$^{93}$ Even if $P$ is neither a donor nor an intermeddler, he is unlikely to receive money restitution for a benefit $D$

159 comment a (1936). Payment of a rental exceeding his profit would leave the defrauded purchaser with a net loss. If $A$ pays $B \$ 10,000$ in exchange for $B$ 's promise not to press criminal charges against $A$ 's relative who has embezzled $\$ 8000$ from $B, A$ is a victim of duress and can recover the entire $\$ 10,000$, even though $B$ had an $\$ 8000$ claim against $A$ 's relative. E.g., Quinn v. United States Fidelity \& Guar. Co., 163 Minn. 320, 204 N.W. 156 (1925); Adams v. Irving Nat'l Bank, 116 N.Y. 606, 23 N.E. 7 (1889); 2 G. PALMER, supra note 2, $\$ 9.11$. Restitution is measured not by B's $\$ 2000$ enrichment, but by $A$ 's $\$ 10,000$ coerced deprivation. Restitution in any lesser amount would leave $A$ with a net loss.

91. If the unsolicited benefit can be returned in specie and $D$ retains it, she may be liable for money restitution. D. DOBBS, supra note $8, \S 4.9$, at 303-04. Or she may be deemed to have accepted a contractual offer. J. CALAMARI \& J. PERILlo, supra note $1, \S 2-21$, at 67 ; RESTATEMENT, supra note 1, § 72(2); RESTATEMENT (SECOND), supra note 1, § 69(2). But see 39 U.S.C. § 3009(b) (1976) (unsolicited merchandise received by mail may be retained without obligation).

92. Restitution is unlikely if there has been no involuntary deprivation. For example, when the benefit to $D$ is merely an incidental consequence of $P$ doing something beneficial for himself, $P$ is not entitled to restitution. If $P$ pumps water from his own quarry, and this has the incidental effect of draining $D$ 's quarry as well, $D$ does not have to pay $P$ anything. Ulmer v. Farnsworth, $80 \mathrm{Mc}$. 500 , $15 \Lambda .65$ (1888); see 2 G. PALMER, supra note 2, § 10.7(a); RESTATEMENT OF RESTITUTION $\S 106$ (1936). $D$ 's enrichment has not come at $P$ 's expense ( $D$ is merely the beneficiary of an externality).

93. See D. DoBBs, supra note $8, \S 4.9$. Thus, a repairman cannot obtain restitution for additional repairs on a motorboat if the owner had requested only that the motor be tuned. J.L. Carpenter Co. v. Richardson, 118 Conn. 322, 172 A. 226 (1934). 
never requested and cannot return; such restitution would subject $D$ to a forced exchange. ${ }^{\text {at }}$

In a few situations, however, restitution is awarded to $P$ for an unsolicited benefit intentionally conferred. For example, a physician or hospital providing emergency medical services to an unconscious patient may recover from the patient the market value of the services rendered. ${ }^{95}$ In such circumstances, it is difficult to regard $P$ as either a donor or an officious intermeddler, and $D$ undoubtedly would have agreed to pay for the benefit if bargaining had been possible. Under the Principle of Minimal Coercion, restitution is justified because its interference with $D$ 's liberty is less serious than the deprivation $P$ would suffer were restitution to be denied. ${ }^{96}$

\section{Restitution for an Unsolicited Benefit Conferred by Mistake}

When an unsolicited benefit is conferred by mistake, the transferor's consent is defective, and the transfer is, in a sense, involuntary. Restitution appears to be warranted by the need to avoid an involuntary transfer of wealth. Since $D$, the recipient of the benefit, has no contractual expectancy to protect, restitution is likely to be granted as long as $D$ is restored to the status quo ante and does not suffer a net loss. Under the Principle of Minimal Coercion, it is difficult to justify a coercive remedy that merely shifts a loss from one innocent person to another without promot-

94. For example, when $P$ 's performance of a contract with $D$ 's tenant improves $D$ 's land, $P$ is not entitled to restitution from $D$ if $D$ never requested $P$ 's performance. E.g., Goldberg v. Ford, $188 \mathrm{Md}$. 658, 53 A.2d 665 (1947); Puttkammer v. Minth, 83 Wis. 2d 686, 266 N.W.2d 361 (1978); 2 G. PALMER, supra note $2, \S 10.7(\mathrm{~b})$.

95. Cotnam v. Wisdom, 83 Ark. 601, 104 S.W. 164 (1907); In re Crisan Estate, 362 Mich. 569, 107 N.W.2d 907 (1961); 2 G. PALMER, supra note 2, $\S 10.4$, at 375-77; RESTATEMENT OF RESTITU. TION $\S 116$ \& comment a (1936).

96. There are also situations in which $P$ obtains restitution for his payment of $D$ 's obligation. Assume $P$, a mortgagee, pays taxes owed by $D$, the mortgagor, to prevent foreclosure of a prior tax lien on the real estate. $P$ is subrogated to the government's right against $D$. Wyoming Bldg. \& Loan Ass'n v. Mills Constr. Co., 38 Wyo. 515, 269 P. 45 (1928); 2 G. PAlMER, supra note 2, \$ 10.5(a). If $P$ settles $T$ 's unliquidated tort claim with a payment to $T$, and $D$ is found solely liable for the tort, $P$ can obtain restitution from $D$ to the extent that $P$ 's payment was reasonable. Northwestern Nat'l Casualty Co. v. State Auto. \& Casualty Underwriters, 35 Wis. 2d 237, 151 N.W.2d 104 (1967); Perkins v. Worzala, 31 Wis. 2d 634, 143 N.W.2d 516 (1966); 2 G. PALMER, supra note 2, § 10.6(a). When $P$, who is secondarily liable as a surety, has paid $D$ 's debt to $C, P$ can obtain restitution from $D$ on a direct claim or by way of subrogation to $C$ 's rights against $D$. Knighton v. Curry, $62 \mathrm{Ala}$. 404 (1878); Hazelton v. Valentine, 113 Mass. 472 (1873); Sheridan v. Dudden Implement, Inc., 174 Neb. 578, 119 N.W.2d 64 (1962); RESTATEMENT OF RESTITUTION $\S 76$ \& comment b, $\$ 162$ \& comment b (1936).

In each of these situations, $\boldsymbol{P}$ was merely protecting his own interests or performing his own legal duty; the circumstances negate both donative intent and officious meddling. Because $D$ already has a legal obligation to pay someone, restitution does not really impose a new obligation and thus does not interfere with her liberty in a significant way. Interference with $D$ 's liberty is minimal and is justified, under the Principle of Minimal Coercion, by the need to impose the burden of payment on the wrongdoer (delinquent taxpayer, tortfeasor, or delinquent debtor) in order to promote deterrence. 


\author{
ing greater justice. ${ }^{97}$
}

When $P$ seeks restitution of money paid by mistake or specific restitution of property transferred by mistake, restitution will normally restore both parties to their previous positions without either party suffering a net loss. $^{98}$ In some situations, restitution would subject $D$ to a net loss (a position worse than her status quo ante).$^{98}$ If $D$ is an innocent party, she is likely to have a valid defense to $P$ 's claim for restitution. ${ }^{100}$

97. Although the need to avoid involuntary loss by the mistaken party gets priority over the recipient's liberty to retain a windfall gain, it does not get priority over the recipient's right to be free from harmful interference (interference imposing a net loss).

98. Thus, if $P$ pays his creditor too much or pays a debt a second time, he can obtain restitution of the overpayment. E.g., Haralson County v. Golden, 104 Ga. 19, 30 S.E. 380 (1898); 3 G. PALMER, supra note 2 , $\$ 14.8$; RESTATEMENT OF RESTITUTION $\S \S 18,20$ (1936). When $P$ pays $D$ 's mortgage debt as a result of some mistake, he is entitled to restitution from $D$ by way of subrogation to the claim and lien of the mortgagee. Carter v. Carter, 251 Ala. 598, 38 So. 2d 557 (1949); Stewart v. Stewart, 90 Wis. 516,63 N.W. 886 (1895); 3 G. PALMER, supra note $2, \S 14.18(\mathrm{~b})$. If, as a result of a basic mistake, $P$ has made a gift of money or property that can be returned in specie, and he would not have made the gift if he had known the truth, he is entitled to restitution from the donee. Stone $v$. Stone, 319 Mich. 194, 29 N.W.2d 271 (1947); Deskovick v. Porzio, 78 N.J. Super. 82, 87-89, 187 A.2d 610, 612-13 (1963); 4 G. PALMER, supra note 2, $\$ \S 18.2-18.4$, 18.6; RESTATEMENT OF RESTITU. TION $\$ \S 26(1)(b), 39,49(1)(b)(1936)$.

99. If $P$ constructs an improvement on $D$ 's land in the mistaken belief that he is improving his own land, the traditional ruling is that $P$ cannot obtain money restitution as affirmative relief. Buswell v. Hadfield, 202 Ark. 200, 149 S.W.2d 555 (1941); Billings v. Hall, 7 Cal. 1 (1857); 2 G. PALMER, supra note $2, \S 10.9$ (a); RESTATEMENT OF RESTITUTION $\S 42(1)$ (1936).

If $P$ performs services that benefit $D, P$ mistakenly believing that $D$ has contracted for such services, restitution will be denied. Smith v. Kneisley, 187 Wash. 278, 60 P.2d 14 (1936); 3 G. PALMER, supra note $2, \S 14.15$ (b); RESTATEMENT OF RESTITUTION $\S 41$ (a)(iii) (1936). If, however, $D$ knew that $P$ believed he had a contract, and $D$ nonetheless permitted $P$ to render the services, $P$ can obtain money restitution equal to the market value of his services. Hawkins v. Lange, 22 Minn. 557 (1876); Henrietta Nat'l Bank v. Barrett, 25 S.W. 456 (Tex. Civ. App. 1894); 3 G. PALMER, supra note 2, $\S$ 14.15(b); RESTATEMENT OF RESTITUTION $\S 40$ (c) \& comment $d$ (1936). In this case, $D$ has interfered with $P$ 's freedom of choice.

With respect to both improvements and services, specific restitution is not feasible, and money restitution forces $D$ to pay for something she never bargained for and may not want. See D. DOBBS, supra note $8, \S 11.11$, at 783 . Money restitution thus involves an excessive risk that $D$ will suffer a net loss, a harmful interference with her liberty.

Nonetheless, a number of recent decisions have awarded restitution to the mistaken improver as affirmative relief. See decisions cited in 2 G. PALMER, supra note $2, \S 10.9$ (c). The measure of restitution is the enhanced market value of the land or the cost incurred by $P$, whichever is less. Id. $\S$ 10.9(e). This reduces the risk that $D$ will suffer a net loss and ensures that she does not pay more than necessary to rectify $P$ 's involuntary transfer of wealth. In order to grant restitution and still protect $D$ against harmful interference with her liberty, some courts give $D$ a choice: she may cither pay restitution for the improvement or convey title to $P$ in exchange for the unimproved value of the land. See id. $\S 10.9$ (c).

100. When $P$ has paid money to $D$ through mistake, and $D$ received the money in good faith and in discharge of a third person's debt, $D$ has the defense of "discharge for value," so long as she had a valid claim against the third person and knew she had a claim. Strubbe v. Sonnenschein, 299 F.2d 185 (2d Cir. 1962); Federated Mut. Ins. Co. v. Good Samaritan Hosp., 191 Neb. 212, 214 N.W.2d 493 (1974); Richey v. Clark, 11 Utah 467, 40 P. 717 (1895); 3 G. PALMER, supra note 2, § 16.6. If $P$ has paid money to $D$ because of some mistake, and $D$ uses the money for an expenditure or gift she would not have made in the absence of $P$ 's payment, $D$ has the defense of "change of position." Sawyer v. Mid-Continent Petroleum Corp., 236 F.2d 518, 522 (10th Cir. 1956); 3 G. PALMER, supra note $2, \S 16.8(\mathrm{c})$; RESTATEMENT OF RESTITUTION $\S 142$ comment $b$ (1936). This defense is also open to $D$ if she passes the money on to a third person pursuant to some fiduciary obligation. United States v. Cambridge Trust Co., 300 F.2d 76, 78 (1st Cir. 1962); Hibbs v. First Nat'l Bank, 133 Va. 94, 112 


\section{J. Liberal Principles in the Law of Restitution: A Summary}

Some general observations emerge from the preceding survey of restitutionary remedies. Restitution usually serves the liberal purpose of rectifying an involuntary transfer. If both parties can be restored to their pretransaction positions, restitution is readily granted. Problems arise when restoration of both parties is impossible. Such problems are generally resolved in a manner consistent with liberal principles. Under the Principle of Minimal Coercion, restitution will be granted to $P$ only to the extent that $P$ 's liberty gets priority over $D$ 's liberty. If $D$ has not wrongfully interfered with $P$ 's liberty, $P$ 's liberty ceases to enjoy priority at the point where restitution would subject the innocent $D$ to a serious loss. ${ }^{101}$ Loss will not be shifted from one innocent party to another; such a shift entails coercion without any gain in justice. If $D$ has wrongfully interfered with $P$ 's liberty, $P$ 's liberty gets priority over $D$ 's liberty and $P$ is entitled to restitution that fully compensates him for harm caused by $D$ 's wrong, even if this leaves $D$ with a serious loss. ${ }^{102}$ Such restitution is consistent with the Principle of Causal Responsibility. But this Principle precludes supercompensatory restitution unless $D$ has contractually consented to make such restitution, in which case it is permitted under the Principle of Consent. ${ }^{103}$

Our survey indicates that the law of restitution is usually consistent with liberal principles. ${ }^{104}$ These principles are undercut in some cases by the method used to determine the amount of restitution. ${ }^{105}$ But only in the case of money restitution as a remedy for breach of contract when $P$ is a partially performing seller is the law of restitution wholly incompatible with liberal principles.

S.E. 669 (1922); 3 G. PALMER, supra note 2 , 16.8(a), (b); RESTATEMENT OF RESTITUTION § 143 (1936).

101. Thus, when $P$ has intentionally conferred an unsolicited benefit on $D$, restitution is granted only if it does not seriously interfere with $D$ 's liberty. When $P$ seeks to avoid a contract for mistake, or has mistakenly conferred an unsolicited benefit on $D$, restitution is not granted if it would subject $D$ to a net loss.

102. Thus, when $P$ avoids a contract on the ground of fraud or duress, he will be fully restored to his pre-contract position, regardless of where this leaves $D$.

103. Thus, to remedy a breach of contract, a buyer may recover money paid and a seller may obtain specific restitution, even if the result is supercompensatory.

104. When $P$ is in material breach of contract and seeks restitution, various judicial responses appear to violate the Principle of Minimal Coercion. The law on this issue, however, is so confused and unsettled that it cannot be regarded as a clear exception to any proposition.

When a contract is unenforceable under the statute of frauds, market value restitution is used and may be supercompensatory, an apparent violation of the Principle of Causal Responsibility necessitated by a statutory policy precluding use of the contract terms. Restitution may be regarded as consistent with the Principle of Minimal Coercion. See supra note 77.

105. See supra note 73. 


\section{Conclusion}

Most of the rules governing restitution as a remedy for breach of contract are reasonable and have been accepted without controversy. A buyer plaintiff should be allowed to recover any money he paid to the defendant seller. A seller plaintiff should be awarded specific restitution whenever this is feasible. A seller plaintiff who has fully performed should be denied restitution.

The controversial issue concerns the measure of money restitution for a seller whose partial performance cannot be returned in specie. The prevailing view is that the seller should recover the market value of his partial performance. One opposing view is that money restitution should be limited either by the contract price or the contract rate. This Article presents another opposing view; it concludes that the partially performing seller should be denied money restitution and be limited to his expectancy damages. This conclusion, derived from liberal principles of justice, which usually impel courts to protect personal liberty and minimize coercion, is strengthened by the relative conformity of other areas of restitution law with liberal legal principles.

Restitution serves a worthy purpose when used to rectify involuntary transfers of wealth. But the remedy should be limited within boundaries imposed by liberal principles of justice. A person who breaches a contract does not thereby forfeit her right to have those boundaries respected. 